\title{
PI3K/AKT/mTOR Signalling Inhibitor Chrysophanol Ameliorates Neurobehavioural and Neurochemical Defects in Propionic Acid-induced Experimental Model of Autism
}

\author{
Aarti Sharma \\ Indo Soviet Friendship College of Pharmacy \\ Sidharth Mehan ( $\nabla$ sidh.mehan@gmail.com ) \\ Indo Soviet Friendship College of Pharmacy https://orcid.org/0000-0003-0034-835X
}

\section{Research Article}

Keywords: Autism, PI3K/AKT/mTOR, Chrysophanol, Propionic acid, Cell death, Neuroinflammation

Posted Date: September 20th, 2021

DOI: https://doi.org/10.21203/rs.3.rs-705335/v1

License: (c) (i) This work is licensed under a Creative Commons Attribution 4.0 International License. Read Full License 


\section{Abstract}

Autism spectrum disorder (ASD) is a complex neurodevelopmental disorder characterized by social-communication deficits and repetitive behaviour. Several studies have revealed that overactivation of the PI3K/AKT/mTOR signalling pathways during brain development plays an important role in the pathogenesis of autism. The PI3K/AKT/mTOR signalling pathway overexpression produces neurological abnormalities by increasing cell death, neuroinflammation, and oxidative stress. Chrysophanol, also known as chrysophanic acid, is a natural substance derived from the plant Rheum palmatum, a well-known Chinese herbal remedy with potential pharmacological applications. The purpose of this study was to look into the neuroprotective effect of $\mathrm{CPH}$ on neurobehavioral, molecular, neurochemical, and gross pathological changes in ICV-PPA-induced autism-like rats, with a particular emphasis on its effect on $\mathrm{PI3K} / \mathrm{AKT} / \mathrm{mTOR}$ downregulation in the brain. Furthermore, we looked at how $\mathrm{CPH}$ affected the levels of myelin basic protein (MBP) in rat brain homogenate, as well as apoptotic markers such caspase-3, Bax, and Bcl-2 levels in rat brain homogenate and blood plasma samples. Rats were examined for behavioural abnormalities, like neuromuscular dysfunction using actophotometer, motor coordination by beam crossing task (BCT), depressive behaviour with forced swim test (FST), cognitive deficit, and consolidation of memory using Morris water maze (MWM) task. Prolonged oral CPH administration from day 12 to day 44 of the experimental schedule reduces autistic-like symptoms in PPA-treated rats. In addition, cellular, molecular, cell death markers, neuroinflammatory cytokines, neurotransmitter levels, and oxidative stress indicators have been examined in rat brain homogenates, blood plasma, and CSF samples. The current findings suggest that $\mathrm{CPH}$ also restores the altered neurochemical levels and potentially prevents autism-like gross pathological changes, including demyelination volume in the rat brain.

\subsection{Introduction}

Autism spectrum disorder (ASD) is a severe neurodevelopmental disorder characterized by stereotyped or repetitive behaviour, memory and cognitive dysfunctions, and disturbances in sensory and motor functions(Gvozdjáková et al., 2014; Neumeyer et al., 2019). Early childhood ASD symptoms arise immediately after birth, leading to lifelong disabilities(Jin et al., 2015). Autism-like repetitive and stereotypical behaviours are caused by various neurochemical changes in specific brain regions such as the hippocampus, cerebellum, amygdala, and cerebral cortex (Rahi et al., 2021; Lee et al., 2016; Morimoto et al., 2020; Sacai et al., 2020). Previous studies revealed that a subset of children with autism has gastrointestinal symptoms and abnormal gut microflora (Kang et al., 2018; Finegold et al., 2012).

Autistic patients have higher levels of clostridium and desulfovibrio, which are known to produce short-chain fatty acids like PPA (Finegold et al., 2011). Propionic acid (PPA) is a short-chain fatty acid that easily penetrates the gutblood barrier and can reach the CNS either through the blood-brain barrier or gradually by the monocarboxylate transporter system (Mirza et al., 2019; Shams et al., 2019). PPA accumulates inside cells, inflicting intracellular acidification, causes mitochondrial dysfunction (Mehan et al., 2020), elevates oxidative stress markers (Rahi et al., 2021), alters neurotransmitters (Tiwari et al., 2021), and impairs synaptic transmission in autistic rat brains (Meeking et al., 2020). According to Sharma et al., stereotaxic PPA injection into the cerebral cortex area causes stereotypical behaviour, and neurochemical alterations in experimental models of autism in rats (Sharma et al., 2019).

$\mathrm{PI3K} / \mathrm{AKT} / \mathrm{mTOR}$ signalling pathway is principally involved in different neuronal functions such as synaptic plasticity, neuronal development, consolidation of memory, and protein synthesis (Kassai et al., 2014; Takei et al., 2014). It also regulates various cellular and biological processes, including neuronal growth, axon guidance, proliferation, and differentiation of cells (Rai et al., 2019; Jafari et al., 2019). 
In various brain regions, upregulation of the PI3K/AKT/mTOR signalling pathway has also been linked to cerebral cell proliferation, axonal disruption, and megalocephaly (Kim et al., 2015; Subramanian et al., 2015; Hutsler et al., 2010). The previous study suggests that the PI3K/AKT/mTOR pathway regulates translation in dendritic spines, and therefore its activation increases dendritic spine dysfunction, resulting in autism-like symptoms (Ganesan et al., 2019; Soltani et al., 2017; Maiti et al., 2015). The PI3K/AKT/mTOR pathway overexpression resulted in learning and memory deficits (Sharma and Mehan, 2021), social impairment (Mattioli et al., 2013), and abnormalities in synaptic plasticity ( $\mathrm{Li}$ et al., 2010). The PI3K/AKT/mTOR signalling pathway have also been associated with the pathogenesis of various neurodevelopmental and neuropsychiatric disorders, including depression (Neis et al., 2020), cognitive development-associated brain malformation (Rivière et al., 2012), and epilepsy (Xiao et al., 2015; Brandt et al., 2018).

The $\mathrm{PI3K} / \mathrm{AKT} / \mathrm{mTOR}$ pathways are upregulated in the development of various neurodegenerative disorders, including Huntington's disease (Abd-Elrahman et al., 2019), Alzheimer's disease (Hodges et al., 2018), and brain trauma (Xu et al., 2020). Furthermore, motor neuron diseases such as Multiple Sclerosis (Giacoppo et al., 2017) and Parkinson's disease are caused by dysregulation of the PI3K/AKT/mTOR pathways (Chen et al., 2019).

Interestingly PI3K/AKT/mTOR inhibitors (Wortmannin, LY294002, Rapamycin) were employed in Male Sprague Dawley rats to restore the long-term memory and cognitive deficits (Sui et al., 2008). Rapamycin was also used to treat learning and memory deficits, social interaction deficits, hyperexcitability, and anxiety-like behaviour in autistic rats(Murakami et al., 2019). Fluoxetine is another potential candidate to treat autism (Sun et al., 2016).

The PI3K/AKT/mTOR inhibitors have also been used to treat CNS disorders, including LY294002 in Huntington's disease (Colin et al., 2005), Wortmannin in Parkinson's disease (Jiang et al., 2021), Rapamycin in infantile spasm (Yang et al., 2019) and Subarachnoid Hemorrhage (Li et al., 2019). PI3K/AKT/mTOR inhibitors also show beneficial effects in various brain diseases such as Fingolimod in Ischemic brain Injury (Li et al., 2019), Sulforaphane in Alzheimer disease (Yang et al., 2020), Propofol in Subarachnoid hemorrhage (Zhang et al., 2019) and Everolimus in Alzheimer disease (Cassano et al., 2019).

Chrysophanol $(\mathrm{CPH})$ is a 1, 8-dihydroxy-3-methyl derivative of the 9, 10-anthracenedion ring first identified from rheum rhubarbarum to a herbaceous perrinary plant belonging to the Polygonaceae family (Singh et al., 2013). CPH has a wide spectrum of pharmacological effects and biological activities such as anti-depressant, anti-bacterial (Rokaya et al., 2012), and anti-cancer (Su et al., 2020). CPH also has anti-microbial, anti-inflammatory (Lu et al., 2016), antiviral properties (Lian et al., 2017), and is used in the treatment of various neurodegenerative diseases (Chae et al., 2017; Jeong et al., 2018).

Preclinical studies revealed that $\mathrm{CPH}$ improves cognition deficits and neuronal loss against streptozotocin-induced diabetic encephalopathy (Chu X et al., 2018). CPH has been shown to provide neuroprotection in various motor neuron illnesses, including MS (Lee et al., 2017) and PD (Chae et al., 2017). CPH is also associated with ameliorating cerebral ischemia/reperfusion injury.

To summarize the interaction of $\mathrm{CPH}$ with potential targets, Wang and Lvvalidated the interaction of $\mathrm{CPH}$ with $\mathrm{mTOR}$ against malignant meningioma by inhibiting mTOR signalling and activating NF2 signalling. Previous studies on colorectal cancer (Deng et al., 2019) and colon cancer (Lee et al., 2011) found that CPH decreased the $\mathrm{PI} 3 \mathrm{~K} / \mathrm{AKT} / \mathrm{mTOR}$ level, alleviating the conditions.

Based on the above findings, we hypothesize that $\mathrm{CPH}$ can downregulate the aberrant PI3K/AKT/mTOR signalling mechanisms, thereby alleviating the neuropathological abnormalities in PPA-induced autism-like rats. In addition, 
$\mathrm{CPH}$ as a $\mathrm{PI3K} / \mathrm{AKT} / \mathrm{mTOR}$ inhibitor can be a novel therapeutic option for autism patients and other neurodevelopmental disorders.

Therefore, the current study investigated the upregulation of PI3K/AKT/mTOR involved in the pathogenesis of Autism. We examined the neuroprotective effect of $\mathrm{CPH}$ on behavioural, neurochemical and morphological characteristics in ICV-PPA-induced autism in rats. CPH shows neuroprotection in autistic rats by downregulation of the PI3K/AKT/mTOR signalling pathway, which was confirmed by studying neurochemical parameters in biological samples such as CSF, blood plasma and brain homogenates.

\subsection{Materials And Methods}

\section{Experimental animals}

A total of 36 rats were used in the current study. All experiments were conducted on six-month-old adult Wistar rats' weight 250-300 g. Each group contains six rats, either sex; they were obtained from the Central Animal House, ISF College of Pharmacy, Moga, Punjab. India. Animals were housed in an acclimatized environment with a 12-hour lightdark cycle with food and water at room temperature at $23 \pm 2{ }^{\circ} \mathrm{C}$. The Institute for Animal Ethics Committee (IAEC) approved the project as 816/PO/ReBiBt/S/04/CPCSEA as IAEC/CPCSEA/Meeting No: 27/2020/Protocol No. 454, following the guidelines provided by the government of India. The rats were randomly divided into six groups based on a validated animal sampling method by Charan and\& Kantharia, 2013. Animals were acclimatized to laboratory conditions before experimentation.

\section{Drugs and chemicals}

PPA was purchased from Sigma-Aldrich (USA). CPH was provided as an ex-gratia sample from BAPEX, India. All other chemicals utilized in the experiments are of analytical grade. Before using the drugs and chemicals, fresh solutions were prepared. CPH was given orally by dissolving in an aqueous solution of $2 \%$ ethanol (Chu et al., 2018). The dosing of chrysophanol was determined based on previous research findings in various brain diseases, including ischemic brain injury (Zhao et al., 2016), learning and memory deficits (Dong et al., 2010), cognition deficits and neuronal loss (Chu et al., 2018), and Cerebral Ischemia (Zhang et al., 2014).

\section{Experimental grouping of animals}

The total duration of the experimentation was of 44 days. Propionic acid (PPA) was injected from day 1 st to day 11 th into the intracerebroventricular (ICV) region of the rat brain to induce autism. CPHwas administered orally from day 12th to day 44th. Animals were randomly assigned into six groups. Group 1- vehicle control; Group 2- sham

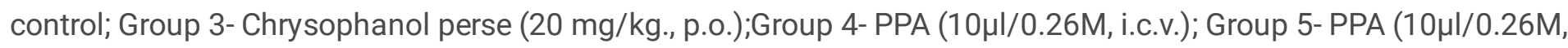
i.c.v. $)+$ Chrysophanol (10 mg/kg., p.o.);Group 6- PPA (10 $\mu \mathrm{l} / 0.26 \mathrm{M}$, i.c.v. $)+$ Chrysophanol (20 mg/kg., p.o.). The present study was unblinded, and the experimenter was known regarding the care of animals. All behavioral parameters were conducted from day 1 to day 44th. On day45th, after completing the protocol schedule, the blood plasma, CSF was collected from adult Wistar rats. Besides, Sodium pentobarbital $270 \mathrm{mg} / \mathrm{ml}$, i.p., was used to anaesthetize the animals deeply. After anesthetization, the fresh brain was removed and preserved with ice-cold PBS (0.1 M) PBS for further neurochemical analysis. The experimental protocol is summarized in (Fig. 1). 


\section{Experimental animal model of ICV-PPA induced autism in rats}

The PPA-induced experimental model of Autism in rats was established and validated by Tiwari et al., 2021. Experimental rats were treated with a PPA-ICV injection of $10 \mu \mathrm{l} / 0.26 \mathrm{M}$ for consecutive 11 th days. The study by Rahi et al., 2021 suggests that PPA causes behavioral and neurochemical alteration similar to an experimental animal model of autism and is regarded as a validated experimental model for researching the pathophysiological changes identical to those seen in Autistic patients.

Rats were allowed to be habituated in a laboratory environment. Eventually, rats were anesthetized by intraperitoneal injection of $75 \mathrm{mg} / \mathrm{kg}$ ketamine. Then, the rats were placed on the stereotaxic instrument (Stoelting Co., Wood Dale, IL, USA) in a skull-flat position. The positioning of the head was adjusted prior to the surgery to ensure that the bregma and lambda coordinates were similar and at the same level. The rats' heads were shaved, the scalp had been cleaned with $70 \%$ ethanol and incised with a blade (mid-sagittal), the skin was removed, and the skull was exposed to spot bregma and lambda that was indicated to assist in defining ICV injection coordinates. Wet cotton swabs were put on rat eyes to prevent dehydration, and cotton buds were used to stop bleeding. A hole was drilled in the skull (Stereotaxic coordinates: $\mathrm{AP}=-1.3 \mathrm{~mm}$; $\mathrm{ML}=-1.8 \mathrm{~mm}$; $\mathrm{DV}=-3.0 \mathrm{~mm}$ ), a cannula inserted in the burr hole, and the cannula was closed using a plastic ear-pin. The dental cement was filled in the hole and then sutured with an absorbable surgical suture attached to the sterile surgical needle (Gonzalez-Fraguela et al., 2013).

For post-operative care, rats were kept independently in a polyacrylic cage that contains warm cloth. Special care was needed until they restored spontaneous movement, which occurred approximately 2-3 hours after anesthesia. The room temperature was set at $25 \pm 3^{\circ} \mathrm{C}$. For $2-3$ days, milk and glucose water are provided inside the cages to avoid physical trauma after surgery. To prevent sepsis, gentamycin $(35 \mathrm{mg} / \mathrm{kg})$ was given intraperitoneally for three days, and lignocaine gel was applied to the sutured area to relieve the pain. Neosporin powder was sprinkled on them to prevent bacterial infection of the skin. After surgery, the body's overall health and clinical symptoms such as dehydration, body weight, infection, and other physical changes were closely monitored.

\subsection{Parameters}

\section{Measurement of weight variations}

\section{Assessment of body weight}

The body weight was measured on the 1st, 13th, 23rd, 33th, and 43rd days of the experiment protocol schedule (Sharma et al., 2019).

\section{Measurement of relative brain-body weight ratio}

The relative brain-body weight ratio was calculated on the 45th day of the experimental protocol schedule (Gopi et al., 2019).

\section{Behaviour parameters}




\section{Morris water maze task (MWM)}

The Morris water maze test was conducted to evaluate memory and cognitive impairment (Morris, 1984). Escape latency time (ELT) was measured using MWM on the 40th, 41st, 42nd, and 43rd, days of the protocol schedule. Time (seconds) taken by rats to reach the target platform was considered as escape latency. On day $44^{\text {th, }}$ rats were exposed to swim in the pool containing a hidden platform; for 120 seconds, and time spent in the target quadrant (TSTQ) was recorded. The TSTQ represents the degree of memory consolidation, which occurred after learning (Duggal et al., 2020).

\section{Locomotor activity}

The locomotor activity was performed on the 1st, 13th, 23rd, and 43rd days of the experimental protocol schedule using an actophotometer (INCO Group of Companies Dubai, United Arab Emirates). The behaviour parameter was evaluated using the method described by Mehan et al., 2018. The animal was placed in a digital actophotometer equipped with infrared photocells. They are then observed for five minutes in a square, the closed arena. The value of a digital actophotometer begins as counts per 5 minutes (Mehan et al., 2018).

\section{Beam crossing task (BCT)}

The beam crossing task was conducted on days 1st, 13th, 23rd, and 43rd of the experimental protocol schedule to evaluate motor coordination ability. During each trial, the number of foot slips was recorded, and additionally, the direction of an animal's fall was observed against the cut-off time of five minutes (Sharma et al., 2019).

\section{Forced swim test (FST)}

The forced swim test was used to measure the depressive-like behaviour of rats on the 1st, 13th, 23rd, and 43rd days. The first exposure of rats in the tank during the training phase is for 15 minutes, and the second is after 24 hours later for 5 minutes. A single six-minute exposure is used during the testing session. The first two minutes serve as a habituation period, with the final four minutes serving as the test itself, which determines the length of immobility (Minj et al., 2021).

\section{Neurochemical parameters}

\section{Collection and preparation of biological samples}

\section{Blood plasma collection and separation}

On day 45th of the protocol schedule, anesthetized the rats with the chloroform before sample collection. Immediately after anesthetization, a capillary tube is placed at the medial canthus of the eye, and then the sinus is ruptured. Instantly 1-2 $\mathrm{ml}$ of blood was collected from the rats through retro-bulbar puncture (Kumar et al., 2017). The obtained blood samples were then cold centrifuged at $10,000 \times \mathrm{g}$ for 15 minutes to separate the plasma. Then separated plasma was carefully stored at $-80^{\circ} \mathrm{C}$ deep freezer for biochemical analysis. 


\section{CSF collection}

Rats were deeply anaesthetized with $270 \mathrm{mg} / \mathrm{ml}$ sodium pentobarbital through i.p. injection. The rats' head was fixed using a holder to reveal the Arachnoid membrane and a skin incision was made, and a translucent dura mater was exposed. A maximum volume of $100 \mu \mathrm{L}$ CSF was obtained by direct inserting a 30-gauge needle at a $30^{\circ}$ angle into the cisterna magna. Within 20 minutes after collection, the sample was centrifuged at $2000 \mathrm{~g}$ for 10 minutes at $4^{\circ} \mathrm{C}$. After centrifugation, the supernatant was stored at $-80^{\circ} \mathrm{C}$ until further analysis(Kozler et al., 2015).

\section{Brain homogenate preparation}

Rats were sacrificed by decapitation on the 45th day of the treatment schedule. The whole fresh brain was removed, washed with ice-cold isotonic saline solution, and homogenized with $0.1 \mathrm{M}(\mathrm{w} / \mathrm{v})$ of chilled phosphate buffer saline $(\mathrm{pH}=7.4)$. The rat brain homogenate was then centrifuged at $10,000 \times \mathrm{g}$ for 15 minutes, the supernatant was separated, and the aliquots were preserved. The samples were stored in a deep-freezer at $-80^{\circ} \mathrm{C}$ to be used as and when the need for various neurochemical estimations (Rahi et al., 2021).

\section{Assessment of cellular and molecular markers}

\section{Estimation of PI3K, AKT and mTOR level}

PI3K protein level was measured in rat brain homogenate (David et al., 2015) and CSF (Tong et al., 2019) using an ELISA kit. According to the instruction given by ELISA assay kits (E-EL-H1019/PI3K; Elabsciences, Wuhan, Hubei, China). The AKT level was estimated in rat brain homogenate (Schipper et al., 2000) and CSF (Dong et al., 2018) (EAB-21082/AKT; Elabsciences, Wuhan, Hubei, China), mTOR level was measured in rat brain homogenate (Wang et al., 2017) and CSF (Li et al., 2015) samples (E-EL-H1655/mTOR; Elabsciences, Wuhan, Hubei, China).

\section{Estimation of MBP level}

The MBP levels were assessed in rat brain homogenate using an ELISA kit (E-EL-R0642/MBP; Elabsciences, Wuhan, Hubei, China). The values were expressed in $\mu \mathrm{g} / \mathrm{mg}$ protein (Rahi et al.,2021).

\section{Assessment of Apoptotic Markers}

Caspase-3 concentrations were assessed in brain homogenate (Rahi et al., 2021) and blood plasma (Guo et al., 2018) using an ELISA kit. Bax protein level was determined in brain homogenate (Tiwari et al., 2021) and blood plasma (Wang et al., 2019). The anti-apoptotic protein such as Bcl-2 levels was estimated in brain homogenate (Sharma et al., 2019) and blood plasma (Wang et al., 2018) using ELISA commercial kits (E-EL-R0160/Caspase-3; EEL-R0098/Bax/Bcl2Elabsciences, Wuhan, Hubei, China). The values are expressed in ng/gm protein in brain homogenate and $\mathrm{ng} / \mathrm{ml}$ in blood plasma.

\section{Assessment of neurotransmitter levels}




\section{Measurement of Acetylcholine (Ach) level}

Acetylcholine level was measured using a diagnostic kit (E-EL-008Ach; ELabSciences, Wuhan, Hubei, China). All samples and reagents were freshly prepared as per manual instruction provided by the kit's. The optical density of the reaction mixture was measured at $540 \mathrm{~nm}$. The neurotransmitter in the supernatant was estimated and the value expressed as ng/mg protein (Rajdev et al., 2020).

\section{Measurement of dopamine level}

The dopamine levels in the striatal tissue sample were determined. Dopamine levels in the striatum are a sign of neural excitability, which leads to mood changes. The electrochemical detector was used to assess dopamine levels in the brain homogenate using the HPLC technique. The level of dopamine in brain homogenates is expressed as ng/mg protein (Sharma et al., 2021).

\section{Estimation of glutamate level}

Glutamate was assessed after derivatization with o-phthalaldehyde/-mercaptoethanol (OPA/-ME), and quantitative analysis in tissue samples was carried out according to Rahi and her coworker's method. The glutamate level in rat brain homogenate is expressed as $\mathrm{ng} / \mathrm{mg}$ protein (Sharma et al., 2019).

\section{Measurement of serotonin level}

Serotonin level was measured in the brain homogenate sample by HPLC using an electrochemical detector and C18 reverse-phase column. The mobile phase consisted of sodium citrate buffer ( $\mathrm{pH} 4.5)$ - acetonitrile $(87: 13, \mathrm{v} / \mathrm{v})$. The supernatant was filtered through $0.22 \mathrm{~mm}$ nylon filters before being injected into the sample injector. The serotonin concentration was assessed from the standard curve generated using a standard with a concentration of 10-100 $\mathrm{mg} / \mathrm{ml}$ (Sharma et al., 2019).

\section{Measurement of inflammatory cytokines levels}

The level of TNF was determined in rat brain homogenate (Mehan et al., 2018) and Blood plasma (Fu et al., 2021) by using a rat immunoassay kit. The activity of IL-1 $\beta$ was assessed in rat brain homogenate (Minj et al., 2021) and blood plasma (Nwangwu et al., 2017) (E-EL-R0019/TNF-a; E-EL-R0012/IL-1ß; ELabSciences, Wuhan, Hubei, China) and value expressed as pg/mg protein (Yu et al., 2018).

\section{Evaluation of oxidative stress markers}

\section{Estimation of acetylcholinesterase (AChE) level}

Acetylcholinesterase concentration was estimated using spectrophotometrically. The assay mixture contained 0.05 $\mathrm{ml}$ of supernatant, $3 \mathrm{ml}$ of $0.01 \mathrm{M}$ sodium phosphate buffer $(\mathrm{pH} 8), 0.10 \mathrm{ml}$ of acetylthiocholine iodide, and $0.10 \mathrm{ml}$ 

enzymatic activity in the supernatant was expressed as $\mu \mathrm{M} / \mathrm{mg}$ protein (Deshmukh et al., 2009).

\section{Measurement of superoxide dismutase (SOD) enzymatic activity}

SOD activity was measured using spectrophotometrically by auto-oxidation of epinephrine at $\mathrm{pH} 10.4$. The supernatant $(0.2 \mathrm{ml})$ of the brain homogenate was mixed with $0.8 \mathrm{ml}$ of $50 \mathrm{mM}$ glycine buffer, $\mathrm{pH} 10.4$, and the reaction was initiated with the addition of $0.02 \mathrm{ml}$ epinephrine. After 5 minutes, the absorbance was spectrophotometrically measured at 480nm. SOD activity was quantified as nM/mg protein (Mehan et al., 2017).

\section{Estimation of GSH level}

The level of reduced glutathione in the brain was assessed using the method described by Ellman et al. $1959.1 \mathrm{ml}$ supernatant was precipitated with $1 \mathrm{ml}$ of $4 \%$ sulfosalicylic acid and cold digested at $4^{\circ} \mathrm{C}$ for one hour. The samples were centrifuged at $1200 \times \mathrm{g}$ for $15 \mathrm{~min}$. To $1 \mathrm{ml}$ of the supernatant, $2.7 \mathrm{ml}$ of phosphate buffer $(0.1 \mathrm{M}, \mathrm{pH} 8)$ and 0.2 $\mathrm{ml}$ of 5,5'-dithiobis-(2-nitrobenzoic acid) (DTNB) were added. The yellow colour appeared immediately measured with a spectrophotometer at $412 \mathrm{~nm}$. The glutathione concentration in the supernatant was expressed as $\mu \mathrm{M} / \mathrm{mg}$ protein (Bala et al., 2015).

\section{Estimation of nitrite level}

The nitrite concentration in the supernatant, indicating the formation of nitric oxide (NO) is evaluated by a colorimetric assay using a Greiss reagent $(0.1 \% \mathrm{~N}-(1$ - naphthyl) ethylenediamine dihydrochloride, $1 \%$ sulfanilamide, and $2.5 \%$ phosphoric acid) as described by Green et al. 1982. Equal volumes of supernatant and Greiss reagent are mixed, the mixture incubated for $10 \mathrm{~min}$ at room temperature in the dark, and the absorbance determined spectrophotometrically at $540 \mathrm{~nm}$. The amount of nitrite in the supernatant is determined from a sodium nitrite standard curve and expressed as $\mu \mathrm{M} / \mathrm{mg}$ protein (Mehan et al., 2020).

\section{Estimation of malondialdehyde (MDA) level}

The quantitative determination of malondialdehyde (MDA) was performed in brain homogenate. After its reaction with thiobarbituric acid, the concentration of MDA was measured at 532nm using a spectrophotometer and expressed as $\mathrm{nM} / \mathrm{mg}$ protein (Mehan et al., 2011).

\section{Protein estimation}

The protein content was quantified by using the Coral protein estimation kit (Biuret method).

\section{Gross pathological examination of rat brains}

On the 43rd day, rats were sacrificed by decapitation; brains were removed for gross pathological analysis performed. After analysing the whole brain, coronal sections were taken (Tiwari et al., 2021). Sectioned 2-mm thick brain pieces (coronally from the anterior pole to the posterior poles of the cerebral cortex) were placed on glass slides. A digital 
camera (Fujix digital camera, Fujifilm, Japan) was used to visualize all the brain regions. The demyelination region $(\mathrm{mm})$ in each brain segment was measured on day 43rd after completing the procedure through MOTICAM-BA310 image plus 2.0 analysis software. The demyelination scale $(\mathrm{mm})$ volume was calculated for each coronal brain segment by converting the demyelination region $(\mathrm{mm})$. The demyelination size $\left(\mathrm{mm}^{3}\right)$ in each brain section was measured from the dark greyish area near the striatum by image analysis on the 43rd day. The injury's size was calculated in each coronal 2-mm-thick brain section by calculating the demyelination area (l×b×h) (Rahi et al., 2021).

\subsection{Statistical Analysis}

Data were analyzed using two-way ANOVA followed by Post hoc test Bonferroni and one-way ANOVA repeated measures followed by Post hoc test Tukey's multi comparison test. $\mathrm{P}<0.001$ was considered statistically significant. Data was found to be normalized, and the sample size was calculated by checking the normality distribution by the Kolmogorov Smirnov test. All statistical results were performed out by GraphPad Prism version 5.03 for Windows (GraphPad Software, San Diego, CA, USA). Statistical results were expressed as the mean \pm standard deviation (SD).

\subsection{Results}

\subsection{Effect of chrysophanol on weight variations in ICV-PPA induced autism in rats}

\section{Restoration of body weight after chronic administration with chrysophanol}

Body weight was assessed on the 1st, 13th, 23rd, 33th, and 43rd days of the protocol schedule. Before initiation of treatment, there was no substantial difference in body weight between all treatment groups. Daily PPA-injection for 11 consecutive days' rats exhibited decreased body weight on the 13th day compared to a vehicle, sham, and $\mathrm{CPH} 20$ perse treated groups. Prolonged oral administration with $\mathrm{CPH} 10 \mathrm{mg} / \mathrm{kg}$ and $\mathrm{CPH} 20 \mathrm{mg} / \mathrm{kg}$ showed significant restoration in body weight on the 23rd, 33th, and 43rd days as compared to PPA-treated autistic rats [two-way ANOVA: $F(20,120)=157.72, \mathrm{p}<0.001]$. CPH $20 \mathrm{mg} / \mathrm{kg}$ was found to be more effective than $\mathrm{CPH} 10 \mathrm{mg} / \mathrm{kg}$ in successfully recovering body weight on the 43rd day (Fig. 2a).

\section{Restoration of relative brain-body weight ratio after chronic administration with chrysophanol}

The relative brain-body weight ratio was evaluated on the last day of the protocol schedule. On the 43rd day, no significant difference in the relative brain-body weight ratio was observed among all groups. Chronic ICV injection of PPA for 11 days caused a significant reduction in relative brain-body weight ratio compared to the vehicle, sham, and $\mathrm{CPH} 20$ perse treatment groups. Long-term administration of $\mathrm{CPH} 20 \mathrm{mg} / \mathrm{kg}$ and $\mathrm{CPH} 10 \mathrm{mg} / \mathrm{kg}$ resulted in an increase in relative brain-body weight ratio on the 43rd day as compared to PPA-treated autistic rats [one-way ANOVA: $F(5,25)=1.218, \mathrm{p}<0.001]$. While $\mathrm{CPH} 20 \mathrm{mg} / \mathrm{kg}$ remarkably restored the relative brain-body weight ratio compared to the $\mathrm{CPH} 10 \mathrm{mg} / \mathrm{kg}$ treated group (Fig. 2b). 


\subsection{Effect of chrysophanol in the amelioration of neurobehavioral alterations in propionic acid-induced autism in rats}

\section{Improvement in memory and cognition after chronic administration with chrysophanol}

The Morris water maze test was conducted to evaluate memory and cognitive impairment. The escape latency was assessed on the 40th, 41st, 42nd, and 43rd, days of the experiment protocol schedule. PPA-treated rats show a progressive increase in escape latency time (ELT) compared to the vehicle, sham, and CPH 20 perse treatment rats. When compared to the PPA-injected group, long-term oral treatment of $\mathrm{CPH} 10 \mathrm{mg} / \mathrm{kg}$ and $\mathrm{CPH} 20 \mathrm{mg} / \mathrm{kg}$ significantly reduced the ELT in a dose-dependent manner [two-way ANOVA: $F(15,90)=19.48, p<0.001$ ]. Furthermore, $\mathrm{CPH} 20 \mathrm{mg} / \mathrm{kg}$ administered in rats decreased the ELT more efficiently than CPH $10 \mathrm{mg} / \mathrm{kg}$ treated animals (Fig. 2c). The time spent in the target quadrant (TSTQ) was recorded on the 44th day of the protocol schedule. Chronic PPAinfused rats have significantly lower TSTQ than vehicle, sham, and CPH 20 perse treated rats. Long term administration with $\mathrm{CPH} 10 \mathrm{mg} / \mathrm{kg}$ and $20 \mathrm{mg} / \mathrm{kg}$ increases the TSTQ in dose-dependent manner compared with PPA-treated autistic rats [one-way ANOVA: $F(5,25)=6.594, p<0.001$ ] $\mathrm{CPH} 20 \mathrm{mg} / \mathrm{kg}$-treated rats were more capable of increasing TSTQ and consolidating memory than $\mathrm{CPH} 10 \mathrm{mg} / \mathrm{kg}$-treated rats (Fig. 2d).

\section{Improvement in locomotion after chronic administration with chrysophanol}

The locomotor activity was used to observe the movement of rats. The test was performed on the $1 \mathrm{st}, 13 \mathrm{th}, 23 \mathrm{rd}$, and 43rd days using the actophotometer apparatus. There were no wide variations between all treatment groups on the first day of the protocol schedule. On the 13th day, PPA-injected rats showed substantially reduced locomotion compared to the vehicle, sham, and $\mathrm{CPH} 20$ perse treated groups. Persistent oral administration of $\mathrm{CPH} 10 \mathrm{mg} / \mathrm{kg}$ and $\mathrm{CPH} 20 \mathrm{mg} / \mathrm{kg}$ significantly improve the locomotion on 23rd and 43rd days, in comparison with PPA-treated autistic rats [two-way ANOVA: $\mathrm{F}(15,90)=644.72, \mathrm{p}<0.001$ ]. Compared to the $\mathrm{CPH} 10 \mathrm{mg} / \mathrm{kg}$ administered group, $\mathrm{CPH}$ $20 \mathrm{mg} / \mathrm{kg}$ was more effective in improving locomotor activity on the 43rd day (Fig. 2e).

\section{Improved motor coordination after chronic administration with chrysophanol}

The beam crossing task was conducted to evaluate the motor coordination ability of rats. The task was performed on the 1st, 13th, 23rd, and 43rd days. On the first day, no significant differences between treatment groups were found. Chronic PPA-treated rats had a significantly higher number of slips on the 13th day than the vehicle, sham, and $\mathrm{CPH} 20$ perse treated groups. On days 23rd and 43rd, prolonged oral treatment with $\mathrm{CPH} 10 \mathrm{mg} / \mathrm{kg}$ and $\mathrm{CPH} 20$ $\mathrm{mg} / \mathrm{kg}$ significantly reduced the number of slips in a dose-dependent manner compared to the PPA treatment group [two-way ANOVA: $F(15,90)=35.18, \mathrm{p}<0.001]$. On the 43rd day, $\mathrm{CPH} 20 \mathrm{mg} / \mathrm{kg}$ was significantly more effective than $\mathrm{CPH} 10 \mathrm{mg} / \mathrm{kg}$ in reducing slip count and improving beam efficiency (Fig. 2f). 


\section{Reduced depression-like behavior after chronic administration with chrysophanol}

The forced swim test was used to measure the depressive-like behavior of rats. The immobility time was measured on the 1st, 13th, 23rd, and 43rd days. On the first day, there was no significant difference between any treatment groups. Compared to the vehicle, sham, and $\mathrm{CPH} 20$ perse treatment groups, PPA-injected rats have longer immobility duration considerably on the 13th day of the protocol schedule. On 23th and 43rd days, long-term oral administered rats with $\mathrm{CPH} 10 \mathrm{mg} / \mathrm{kg}$ and $\mathrm{CPH} 20 \mathrm{mg} / \mathrm{kg}$ dramatically reduces the immobility time in a dose-dependent manner as compared with PPA treated rats [two-way ANOVA: $F(15,90)=910.07, p<0.001]$. CPH $20 \mathrm{mg} / \mathrm{kg}$, on the other hand, was found to be more successful in significantly reducing immobility time and recovering depressive-like behavior on the 43rd day than $\mathrm{CPH} 10 \mathrm{mg} / \mathrm{kg}$ treatment group (Fig. $2 \mathrm{~g}$ ).

\subsection{Effect of chrysophanol on neurochemical alterations in ICV- PPA induced autism in rats}

\section{Decreased PI3K level after chronic administration with chrysophanol}

PI3K protein level was measured in rat brain homogenate and CSF samples at the end of the experimental protocol schedule. PPA-treated rats show a considerable increase in the PI3K protein level in rat brain homogenate and CSF compared to the vehicle, sham, and $\mathrm{CPH} 20$ perse treated group. Long-term oral administration with $\mathrm{CPH}$ at the doses of $10 \mathrm{mg} / \mathrm{kg}$ and $20 \mathrm{mg} / \mathrm{kg}$ for 44 days consistently decreases the PI3K level compared to PPA-treated rats. In comparison with $\mathrm{CPH} 10 \mathrm{mg} / \mathrm{kg}$ treatment group, $\mathrm{CPH} 20 \mathrm{mg} / \mathrm{kg}$ treatment group was proven to be more effective in the reduction of PI3K level in rat brain homogenate [one-way ANOVA: $F(5,25)=1.136, p<0.001$ ] and CSF samples [one-way ANOVA: $F(5,25)=0.256, p<0.001$ ]. (Table 1a) 
Table 1

Effect of chrysophanol on PI3K, AKT, mTOR and myelin basic protein level in propionic acid-induced autism in rats

\begin{tabular}{|c|c|c|c|c|c|c|c|c|}
\hline \multirow[t]{2}{*}{$\begin{array}{l}\text { S. } \\
\text { no. }\end{array}$} & \multirow[t]{2}{*}{ Groups } & \multicolumn{2}{|l|}{ PI3K } & \multicolumn{2}{|l|}{ AKT } & \multicolumn{2}{|l|}{ mTOR } & \multirow{2}{*}{$\begin{array}{l}\text { Myelin basic } \\
\text { protein } \\
\text { Brain } \\
\text { homogenate } \\
\text { ( } \mu \mathrm{g} / \mathrm{mg} \\
\text { protein) }\end{array}$} \\
\hline & & $\begin{array}{l}\text { Brain } \\
\text { homogenate } \\
\text { (pg/g } \\
\text { protein) }\end{array}$ & $\begin{array}{l}\text { CSF } \\
(\mathrm{ng} / \mathrm{ml})\end{array}$ & $\begin{array}{l}\text { Brain } \\
\text { homogenate } \\
\text { (pg/g } \\
\text { protein) }\end{array}$ & $\begin{array}{l}\text { CSF } \\
(\mathrm{ng} / \mathrm{ml})\end{array}$ & $\begin{array}{l}\text { Brain } \\
\text { homogenate } \\
\text { (ng/g } \\
\text { protein) }\end{array}$ & $\begin{array}{l}\text { CSF } \\
(\mathrm{ng} / \mathrm{ml})\end{array}$ & \\
\hline 1. & $\begin{array}{l}\text { Vehicle } \\
\text { control }\end{array}$ & $\begin{array}{l}7.133 \pm \\
0.142\end{array}$ & $\begin{array}{l}2.312 \pm \\
0.092\end{array}$ & $\begin{array}{l}3.682 \pm \\
0.103\end{array}$ & $\begin{array}{l}0.470 \pm \\
0.031\end{array}$ & $\begin{array}{l}1.332 \pm \\
0.081\end{array}$ & $\begin{array}{l}7.485 \pm \\
0.083\end{array}$ & $\begin{array}{l}110.3 \pm \\
1.972\end{array}$ \\
\hline 2. & $\begin{array}{l}\text { Sham } \\
\text { control }\end{array}$ & $\begin{array}{l}7.123 \pm \\
0.116\end{array}$ & $\begin{array}{l}2.277 \pm \\
0.105\end{array}$ & $\begin{array}{l}3.743 \pm \\
0.095\end{array}$ & $\begin{array}{l}0.465 \pm \\
0.029\end{array}$ & $\begin{array}{l}1.308 \pm \\
0.077\end{array}$ & $\begin{array}{l}7.415 \pm \\
0.129\end{array}$ & $\begin{array}{l}110.1 \pm \\
2.133\end{array}$ \\
\hline 3. & $\begin{array}{l}\mathrm{CPH} 20 \\
\text { perse }\end{array}$ & $\begin{array}{l}7.070 \pm \\
0.130\end{array}$ & $\begin{array}{l}2.298 \pm \\
0.097\end{array}$ & $\begin{array}{l}3.822 \pm \\
0.076\end{array}$ & $\begin{array}{l}0.460 \pm \\
0.036\end{array}$ & $\begin{array}{l}1.303 \pm \\
0.050\end{array}$ & $\begin{array}{l}7.422 \pm \\
0.084\end{array}$ & $\begin{array}{l}110.7 \pm \\
1.526\end{array}$ \\
\hline 4. & PPA & $\begin{array}{l}28.04 \pm \\
0.158 *\end{array}$ & $\begin{array}{l}4.485 \pm \\
0.091^{\star}\end{array}$ & $\begin{array}{l}19.06 \pm \\
0.197^{\star}\end{array}$ & $\begin{array}{l}1.560 \pm \\
0.020 *\end{array}$ & $\begin{array}{l}7.435 \pm \\
0.101^{\star}\end{array}$ & $\begin{array}{l}11.01 \pm \\
0.069 *\end{array}$ & $\begin{array}{l}50.58 \pm \\
1.040^{\star}\end{array}$ \\
\hline 5. & $\begin{array}{l}\text { PPA + } \\
\text { CPH10 }\end{array}$ & $\begin{array}{l}21.77 \pm \\
0.146 @\end{array}$ & $\begin{array}{l}3.802 \pm \\
0.076 @\end{array}$ & $\begin{array}{l}14.71 \pm \\
0.260 @\end{array}$ & $\begin{array}{l}1.178 \pm \\
0.046 @\end{array}$ & $\begin{array}{l}5.865 \pm \\
0.078 @\end{array}$ & $\begin{array}{l}9.818 \pm \\
0.0875^{@}\end{array}$ & $\begin{array}{l}66.67 \pm \\
1.413^{@}\end{array}$ \\
\hline 6. & $\begin{array}{l}\text { PPA+ } \\
\text { CPH20 }\end{array}$ & $\begin{array}{l}14.16 \pm \\
0.209 @ \#\end{array}$ & $\begin{array}{l}2.795 \pm \\
0.094 @ \#\end{array}$ & $\begin{array}{l}9.202 \pm \\
0.209 @ \#\end{array}$ & $\begin{array}{l}0.858 \pm \\
0.051 @ \#\end{array}$ & $\begin{array}{l}3.532 \pm \\
0.094 @ \#\end{array}$ & $\begin{array}{l}8.792 \pm \\
0.129 @ \#\end{array}$ & $\begin{array}{l}76.91 \pm \\
1.634^{@ \#}\end{array}$ \\
\hline
\end{tabular}

\section{Decreased AKT level after chronic administration with chrysophanol}

The AKT level was estimated in rat brain homogenate and CSF samples by using an ELISA kit. Chronic PPA-injected rats substantially increased AKT level in rat brain homogenate and CSF compare to the vehicle, sham, and $\mathrm{CPH} 20$ perse treatment group. Prolonged oral treatment with $\mathrm{CPH} 10$ and $20 \mathrm{mg} / \mathrm{kg}$ dramatically reduced the AKT level in brain homogenate and CSF than PPA-injected groups. Moreover, $\mathrm{CPH} 20 \mathrm{mg} / \mathrm{kg}$ is found to be more effective in the reduction of AKT level in brain homogenate [one-way ANOVA: $F(5,25)=1.209, p<0.001$ ] and CSF samples [one-way ANOVA: $F(5,25)=0.151, p<0.001]$ than $\mathrm{CPH} 10 \mathrm{mg} / \mathrm{kg}$ treated groups $($ Table $1 \mathrm{~b})$.

\section{Decreased mTOR level after chronic administration with chrysophanol}

The level of mTOR was measured in rat brain homogenate and CSF samples. Long-term PPA-treated rat's exhibit higher mTOR levels in rat brain homogenate and CSF samples than the vehicle, sham, and $\mathrm{CPH} 20$ perse treatment groups. Continuous oral administration of $\mathrm{CPH} 10$ and $20 \mathrm{mg} / \mathrm{kg}$ results a significantly decreases the mTOR level in the rat brain homogenate [one-way ANOVA: $F(5,25)=1.212, p<0.001$ ] and CSF [one-way ANOVA: $F(5,25)=0.551, p<$ 


\section{Restoredmyelin basic protein level after chronic administration with chrysophanol}

Myelin basic protein (MBP) protein level was measure in rat brain homogenates using an ELISA kit. PPA-injected rat's show a remarkable reduction in MBP level compared with vehicle, sham, and $\mathrm{CPH} 20$ perse treated groups. Long-term oral administration with $\mathrm{CPH} 10$ and $20 \mathrm{mg} / \mathrm{kg}$ leads to a massive rise in MBP level compared to the PPA-injected rats [one-way ANOVA: $F(5,25)=1.687, \mathrm{p}<0.001$ ]. $\mathrm{CPH} 20 \mathrm{mg} / \mathrm{kg}$ was more effective in restoring MBP level in rat brain homogenate than the $\mathrm{CPH} 10 \mathrm{mg} / \mathrm{kg}$ treatment group (Table $1 \mathrm{~d}$ ).

\section{Reduction in caspase-3, Bax, and increased Bcl-2 levels after chronic administration with chrysophanol}

The neuronal autophagic indicators such as Caspase-3, Bax, and $\mathrm{Bcl}-2$ were estimated in rat brain homogenate and blood plasma. Chronic PPA treated rat's substantial increases in Caspase-3 and Bax protein levels in rat brain homogenate and blood plasma. Additionally, ICV-PPA treated rats show a considerable reduction in anti-apoptotic $\mathrm{Bcl}-2$ levels in brain homogenate and blood plasma compared to the vehicle, sham, and $\mathrm{CPH} 20$ perse group.Persistent oral CPH treatment with 10 and $20 \mathrm{mg} / \mathrm{kg}$ cause a significant reduction in Caspase-3 level in brain homogenate [one-way ANOVA: $F(5,25)=0.210, p<0.001$ ] and blood plasma[one-way ANOVA: $F(5,25)=1.052, p<$ 0.001].

Similarly, chronic oral $\mathrm{CPH}$ administration at doses of $10 \mathrm{mg} / \mathrm{kg}$ and $20 \mathrm{mg} / \mathrm{kg}$ show a considerable decreased in the level of Bax in rat brain homogenate[one-way ANOVA: $F(5,25)=1.213, p<0.001$ ] and blood plasma samples[one-way ANOVA: $F(5,25)=1.246, p<0.001$ ] as compared to long term PPA-exposed rats, continuous oral treatment with $\mathrm{CPH}$ 10 and $20 \mathrm{mg} / \mathrm{kg}$ for 44 days resulted a substantially increases Bcl-2 level in rat brain homogenate [one-way ANOVA: $F(5,25)=2.193, p<0.001$ ] and blood plasma[one-way ANOVA: $F(5,25)=3.179, p<0.001$ ] Compared to $\mathrm{CPH} 10 \mathrm{mg} / \mathrm{kg}$ treated rats, $\mathrm{CPH} 20 \mathrm{mg} / \mathrm{kg}$ was more efficacious in reducing autophagic markers and restoring anti-apoptotic markers in PPA-induced autistic rats (Table 2). 
Table 2

Effect of chrysophanol on apoptotic markers level in propionic acid-induced autism in rats

\begin{tabular}{|c|c|c|c|c|c|c|c|}
\hline \multirow{3}{*}{$\begin{array}{l}\text { S. } \\
\text { no. }\end{array}$} & \multirow[t]{3}{*}{ Groups } & \multicolumn{2}{|l|}{ Caspase-3 } & \multicolumn{2}{|l|}{ Bax } & \multicolumn{2}{|l|}{ Bcl-2 } \\
\hline & & $\begin{array}{l}\text { Brain } \\
\text { homogenate }\end{array}$ & $\begin{array}{l}\text { Blood } \\
\text { plasma }\end{array}$ & $\begin{array}{l}\text { Brain } \\
\text { homogenate }\end{array}$ & $\begin{array}{l}\text { Blood } \\
\text { plasma }\end{array}$ & $\begin{array}{l}\text { Brain } \\
\text { homogenate }\end{array}$ & $\begin{array}{l}\text { Blood } \\
\text { plasma }\end{array}$ \\
\hline & & $\begin{array}{l}\text { (nM/mg } \\
\text { protein) }\end{array}$ & $(\mathrm{ng} / \mathrm{ml})$ & $\begin{array}{l}\text { (ng/mg } \\
\text { protein) }\end{array}$ & (ng/ml) & $\begin{array}{l}\text { (ng/mg } \\
\text { protein) }\end{array}$ & (ng/ml) \\
\hline 1. & $\begin{array}{l}\text { Vehicle } \\
\text { control }\end{array}$ & $\begin{array}{l}117.4 \pm \\
0.858\end{array}$ & $\begin{array}{l}1.840 \pm \\
0.049\end{array}$ & $9.167 \pm 0.269$ & $\begin{array}{l}0.833 \pm \\
0.035\end{array}$ & $34.69 \pm 0.553$ & $\begin{array}{l}9.208 \pm \\
0.036\end{array}$ \\
\hline 2. & $\begin{array}{l}\text { Sham } \\
\text { control }\end{array}$ & $\begin{array}{l}118.5 \pm \\
0.622\end{array}$ & $\begin{array}{l}1.830 \pm \\
0.043\end{array}$ & $9.098 \pm 0.595$ & $\begin{array}{l}0.846 \pm \\
0.033\end{array}$ & $35.22 \pm 0.437$ & $\begin{array}{l}9.143 \pm \\
0.043\end{array}$ \\
\hline 3. & $\begin{array}{l}\mathrm{CPH} 2 \mathrm{O} \\
\text { perse }\end{array}$ & $\begin{array}{l}117.7 \pm \\
1.156\end{array}$ & $\begin{array}{l}1.858 \pm \\
0.046\end{array}$ & $8.690 \pm 0.310$ & $\begin{array}{l}0.840 \pm \\
0.035\end{array}$ & $34.78 \pm 0.919$ & $\begin{array}{l}9.153 \pm \\
0.054\end{array}$ \\
\hline 4. & PPA & $\begin{array}{l}178.4 \pm \\
1.313^{\star}\end{array}$ & $\begin{array}{l}5.798 \pm \\
0.132\end{array}$ & $\begin{array}{l}15.21 \pm \\
0.359^{\star}\end{array}$ & $\begin{array}{l}5.223 \pm \\
0.092^{\star}\end{array}$ & $\begin{array}{l}23.34 \pm \\
0.530^{\star}\end{array}$ & $\begin{array}{l}1.815 \pm \\
0.056^{\star}\end{array}$ \\
\hline 5. & $\begin{array}{l}\text { PPA+ } \\
\text { CPH10 }\end{array}$ & $\begin{array}{l}161.0 \pm \\
1.461 @\end{array}$ & $\begin{array}{l}3.248 \pm \\
0.136 @\end{array}$ & $\begin{array}{l}13.16 \pm \\
0.387 @\end{array}$ & $\begin{array}{l}4.315 \pm \\
0.152^{@}\end{array}$ & $\begin{array}{l}25.80 \pm \\
0.725 @\end{array}$ & $\begin{array}{l}4.425 \pm \\
0.203 @\end{array}$ \\
\hline 6. & $\begin{array}{l}\text { PPA+ } \\
\text { CPH20 }\end{array}$ & $\begin{array}{l}147.3 \pm \\
1.022^{@ \#}\end{array}$ & $\begin{array}{l}2.493 \pm \\
0.350 @ \#\end{array}$ & $\begin{array}{l}10.92 \pm \\
0.275^{@ \#}\end{array}$ & $\begin{array}{l}2.562 \pm \\
0.301 @ \#\end{array}$ & $\begin{array}{l}29.27 \pm \\
1.022^{@ \#}\end{array}$ & $\begin{array}{l}7.173 \pm \\
0.103^{@ \#}\end{array}$ \\
\hline
\end{tabular}

\section{Restoration of neurotransmitters level after chronic administration with chrysophanol}

Neurotransmitters like serotonin, dopamine, acetylcholine, and glutamate were measured in rat brain homogenate at the end of the protocol schedule. ICV-PPA injected rats caused a massive reduction in dopamine, serotonin, acetylcholine level, and increased glutamate level observed in rat brain homogenate compared to the vehicle, sham, and $\mathrm{CPH} 20$ perse administered rats. Long-term oral treatment with $\mathrm{CPH} 10$ and $20 \mathrm{mg} / \mathrm{kg}$ dramatically increases dopamine [one-way ANOVA: $F(5,25)=2.546, p<0.001$ ], serotonin[one-way ANOVA: $F(5,25)=0.228, p<0.001$ ], and acetylcholine[one-way ANOVA: $F(5,25)=0.479, p<0.001$ ] level while decreased glutamate level was estimated as compare to PPA-infused autistic rats [one-way ANOVA: $F(5,25)=0.807, p<0.001$ ]. Among these, $\mathrm{CPH} 20 \mathrm{mg} / \mathrm{kg}$ was more effective in restoring neurotransmitter levels in rat brain homogenate than the $\mathrm{CPH} 10 \mathrm{mg} / \mathrm{kg}$ treatment group (Table 3). 
Table 3

Effect of chrysophanol on neurotransmitters level in propionic acid-induced autism in rats

\begin{tabular}{|c|c|c|c|c|c|}
\hline \multirow[t]{2}{*}{ S. no. } & \multirow[t]{2}{*}{ Groups } & \multicolumn{4}{|c|}{ Neurotransmitters (Brain homogenate) } \\
\hline & & $\begin{array}{l}\text { Serotonin } \\
\text { (ng/mg protein) }\end{array}$ & $\begin{array}{l}\text { Glutamate } \\
\text { (ng/mg protein) }\end{array}$ & $\begin{array}{l}\text { Dopamine } \\
\text { (ng/mg protein) }\end{array}$ & $\begin{array}{l}\text { Ach } \\
\text { (ng/mg protein) }\end{array}$ \\
\hline 1. & Vehicle control & $46.99 \pm 0.416$ & $119.9 \pm 0.945$ & $102.2 \pm 1.867$ & $9.047 \pm 0.215$ \\
\hline 2. & Sham control & $47.22 \pm 0.519$ & $120.2 \pm 0.518$ & $101.8 \pm 2.186$ & $8.955 \pm 0.279$ \\
\hline 3. & $\mathrm{CPH} 20$ perse & $48.09 \pm 0.517$ & $119.5 \pm 0.809$ & $102.9 \pm 1.852$ & $8.855 \pm 0.189$ \\
\hline 4. & PPA & $17.34 \pm 0.648^{*}$ & $328.4 \pm 1.781^{*}$ & $38.15 \pm 1.265^{\star}$ & $2.392 \pm 0.104^{\star}$ \\
\hline 5 & $\mathrm{PPA}+\mathrm{CPH} 10$ & $24.05 \pm 0.457 @$ & 234.4+1.791@ & $54.84 \pm 0.842 @$ & $4.278 \pm 0.057 @$ \\
\hline 6. & $\mathrm{PPA}+\mathrm{CPH} 20$ & $31.06 \pm 0.407^{@ \#}$ & $198.6 \pm 1.690 @ \#$ & $61.91 \pm 1.163^{@ \#}$ & $5.872 \pm 0.191 @ \#$ \\
\hline
\end{tabular}

\section{Decreased inflammatory cytokines level after chronic administration with chrysophanol}

Inflammatory cytokines such as TNF and IL-1 $\beta$ were measured in rat brain homogenate and blood plasma samples using an ELISA kit. Chronic ICV-PPA treated rat's show significant increases in proinflammatory mediators such as TNF and IL-1 $\beta$ in rat brain homogenate and blood plasma compared to the vehicle, sham, and $\mathrm{CPH} 20$ perse treated groups. However, persistent oral treatment with $\mathrm{CPH} 10$ and $20 \mathrm{mg} / \mathrm{kg}$ results in a substantially decreases in inflammatory cytokines TNF in rat brain homogenate [one-way ANOVA: $F(5,25)=0.357, p<0.001$ ] and blood plasma [one-way ANOVA: $F(5,25)=1.180, p<0.001]$.

Similarly, chronic oral dosing with $\mathrm{CPH} 10$ and $20 \mathrm{mg} / \mathrm{kg}$ markedly decreased the level of IL-1 $\beta$ in rat brain homogenate [one-way ANOVA: $F(5,25)=4.582$, $p<0.001$ ] and blood plasma [one-way ANOVA: $F(5,25)=0.782, p<$ 0.001] as compared with PPA treated rats. However, $\mathrm{CPH} 20 \mathrm{mg} / \mathrm{kg}$ treatment was found to be more efficient in reducing inflammatory cytokines compared with $\mathrm{CPH} 10 \mathrm{mg} / \mathrm{kg}$ treated rats (Table 4). 
Table 4

Effect of chrysophanol on inflammatory cytokines level in propionic acid-induced autism in rats

\begin{tabular}{|c|c|c|c|c|c|}
\hline \multirow[t]{3}{*}{ S. no. } & \multirow[t]{3}{*}{ Groups } & \multicolumn{4}{|c|}{ Inflammatory cytokines } \\
\hline & & \multicolumn{2}{|l|}{ TNF-a } & \multicolumn{2}{|l|}{ IL-1 $\beta$} \\
\hline & & $\begin{array}{l}\text { Brain homogenate } \\
\text { (pg/mg protein) }\end{array}$ & $\begin{array}{l}\text { Blood plasma } \\
(\mathrm{pg} / \mathrm{ml})\end{array}$ & $\begin{array}{l}\text { Brain homogenate } \\
\text { (pg/mg protein) }\end{array}$ & $\begin{array}{l}\text { Blood plasma } \\
\text { (pg/ml) }\end{array}$ \\
\hline 1. & Vehicle control & $37.84 \pm 0.838$ & $30.04 \pm 0.543$ & $18.69 \pm 0.621$ & $13.30 \pm 0.664$ \\
\hline 2. & Sham control & $37.05 \pm 0.548$ & $30.07 \pm 0.363$ & $18.75 \pm 0.627$ & $13.53 \pm 0.336$ \\
\hline 3. & $\mathrm{CPH} 20$ perse & $36.90 \pm 0.267$ & $30.22 \pm 0.382$ & $18.72 \pm 0.702$ & $13.22 \pm 0.100$ \\
\hline 4. & PPA & $80.45 \pm 1.342^{\star}$ & $96.78 \pm 1.545^{\star}$ & $34.89 \pm 0.478 *$ & $83.91 \pm 0.363^{\star}$ \\
\hline 5. & $\mathrm{PPA}+\mathrm{CPH} 10$ & $71.40 \pm 1.370 @$ & 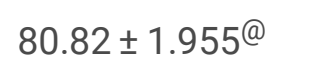 & 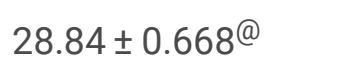 & $69.05 \pm 0.610 @$ \\
\hline 6. & $\mathrm{PPA}+\mathrm{CPH} 20$ & $57.61 \pm 1.850 @ \#$ & $59.98 \pm 0.419 @ \#$ & $23.64 \pm 0.440 @ \#$ & $46.68 \pm 1.080 @ \#$ \\
\hline $\begin{array}{l}\text { (Value } \\
\text { CPH2C } \\
\text { compa }\end{array}$ & $\begin{array}{l}\text { pressed as me } \\
\text { se; @ p }<0.001 \\
\text { n test) }\end{array}$ & SD $(n=6$ rats per $g$ & $\begin{array}{l}\text { p). }{ }^{*} \mathrm{p}<0.001 \mathrm{v} / \mathrm{s} \\
\mathrm{PPA}+\mathrm{CPH} 10 \text { (on }\end{array}$ & icle control, sham c & $\begin{array}{l}\text { rol and } \\
\text { Tukey's multiple }\end{array}$ \\
\hline
\end{tabular}

\section{Amelioration of oxidative stress markers level after chronic administration with chrysophanol}

The levels of oxidative stress indicators AchE, LDH, SOD, GSH, nitrite, and MDA were measured in rat brain homogenate. Chronic PPA administration rats shoed a massive rise in AchE, LDH, nitrite, and MDA levels in rat brain homogenate than the vehicle, sham, and $\mathrm{CPH} 20$ perse treatment groups, ICV-PPA injected groups results in a considerable reduction in anti-oxidant enzyme levels such as SOD [one-way ANOVA: $F(5,25)=0.968, p<0.001$ ] and GSH [one-way ANOVA: $F(5,25)=0.979, p<0.001$ ] in rat brain homogenate as compared to PPA-exposed rats.

Chronic oral treatment with $\mathrm{CPH} 10$ and $20 \mathrm{mg} / \mathrm{kg}$ for 44 days consecutively led toa significantly decreased inAchE[one-way ANOVA: $F(5,25)=1.266, p<0.001$ ], $L D H$ [one-way ANOVA: $F(5,25)=1.584, p<0.001$ ], nitrite [one-way ANOVA: $F(5,25)=0.801, p<0.001$ ], and MDA[one-way ANOVA: $F(5,25)=4.699, p<0.001$ ] levels in brain homogenate. Similarly, continuous oral treatment with $\mathrm{CPH} 10$ and $20 \mathrm{mg} / \mathrm{kg}$ results in a considerable increase in SOD and GSH levels in rat brain homogenate. Likewise, $\mathrm{CPH} 20 \mathrm{mg} / \mathrm{kg}$ is more effective in restoring anti-oxidant enzyme levels than $\mathrm{CPH} 10 \mathrm{mg} / \mathrm{kg}$ treated rats (Table 5). 
Table 5

Effect of chrysophanolon oxidative stress markers level in propionic acid-induced autism in rats

\begin{tabular}{|c|c|c|c|c|c|c|c|}
\hline \multirow[t]{3}{*}{ S.no. } & \multirow[t]{3}{*}{ Groups } & \multicolumn{6}{|c|}{ Oxidative stress markers (Brain homogenate) } \\
\hline & & AchE & LDH & SOD & GSH & Nitrite & MDA \\
\hline & & $\begin{array}{l}(\mu \mathrm{M} / \mathrm{mg} \\
\text { protein) }\end{array}$ & $\begin{array}{l}\text { (Unit/mg } \\
\text { protein) }\end{array}$ & $\begin{array}{l}(\mu \mathrm{M} / \mathrm{mg} \\
\text { protein) }\end{array}$ & $\begin{array}{l}(\mu \mathrm{M} / \mathrm{mg} \\
\text { protein) }\end{array}$ & $\begin{array}{l}(\mu \mathrm{M} / \mathrm{mg} \\
\text { protein) }\end{array}$ & $\begin{array}{l}\text { (nM/mg } \\
\text { protein) }\end{array}$ \\
\hline 1. & $\begin{array}{l}\text { Vehicle } \\
\text { control }\end{array}$ & $\begin{array}{l}23.86 \pm \\
0.971\end{array}$ & $\begin{array}{l}130.1 \pm \\
1.206\end{array}$ & $\begin{array}{l}492.3 \pm \\
2.583\end{array}$ & $\begin{array}{l}38.27 \pm \\
0.790\end{array}$ & $6.89 \pm 0.261$ & $\begin{array}{l}36.91 \pm \\
0.315\end{array}$ \\
\hline 2. & $\begin{array}{l}\text { Sham } \\
\text { control }\end{array}$ & $\begin{array}{l}24.24 \pm \\
0.790\end{array}$ & $\begin{array}{l}125.4 \pm \\
0.545\end{array}$ & $\begin{array}{l}491.9 \pm \\
3.425\end{array}$ & $\begin{array}{l}38.63 \pm \\
0.886\end{array}$ & $7.11 \pm 0.220$ & $\begin{array}{l}37.67 \pm \\
0.622\end{array}$ \\
\hline 3. & $\begin{array}{l}\mathrm{CPH} 20 \\
\text { perse }\end{array}$ & $\begin{array}{l}23.90 \pm \\
0.886\end{array}$ & $\begin{array}{l}126.6 \pm \\
0.628\end{array}$ & $\begin{array}{l}493.1 \pm \\
3.004\end{array}$ & $\begin{array}{l}39.10 \pm \\
0.421\end{array}$ & $6.91 \pm 0.181$ & $\begin{array}{l}37.11 \pm \\
1.079\end{array}$ \\
\hline 4. & PPA & $\begin{array}{l}60.25 \pm \\
1.214^{\star}\end{array}$ & $\begin{array}{l}428.7 \pm \\
1.835^{\star}\end{array}$ & $\begin{array}{l}347.8 \pm \\
1.806\end{array}$ & $\begin{array}{l}10.95 \pm \\
0.422^{\star}\end{array}$ & $\begin{array}{l}13.41 \pm \\
0.458^{\star}\end{array}$ & $\begin{array}{l}80.00 \pm \\
0.880^{\star}\end{array}$ \\
\hline 5. & $\begin{array}{l}\text { PPA + } \\
\text { CPH10 }\end{array}$ & $\begin{array}{l}45.41 \pm \\
0.874 @\end{array}$ & $\begin{array}{l}318.1 \pm \\
1.057 @\end{array}$ & $\begin{array}{l}359.8 \pm \\
0.914 @\end{array}$ & $\begin{array}{l}16.88 \pm \\
0.732 @\end{array}$ & $\begin{array}{l}10.82 \pm \\
0.450 @\end{array}$ & $\begin{array}{l}71.19 \pm \\
0.824 @\end{array}$ \\
\hline 6. & $\begin{array}{l}\mathrm{PPA}+ \\
\mathrm{CPH} 20\end{array}$ & $\begin{array}{l}36.97 \pm \\
1.346 @ \#\end{array}$ & $\begin{array}{l}289.8 \pm \\
2.058 @ \#\end{array}$ & $\begin{array}{l}393.2 \pm \\
2.183 @ \#\end{array}$ & $\begin{array}{l}24.76 \pm \\
0.769 @ \#\end{array}$ & $\begin{array}{l}8.85 \pm \\
0.234 @ \#\end{array}$ & $\begin{array}{l}63.37 \pm \\
0.881 @ \#\end{array}$ \\
\hline
\end{tabular}

\subsection{Effect of chrysophanol in the restoration of gross pathological alterations in ICV-PPA induced autism in rats}

\section{Restoration of whole-brain alterations after chronic administration with chrysophanol}

The normal, vehicle and $\mathrm{CPH} 20$ perse treated groups had the proper brain size and morphology. The ICV-PPA treated rat brains displayed disrupted clotted outermost layer with rupture meninges compared to the vehicle, sham, and $\mathrm{CPH} 20$ perse treatment groups. Prolonged oral administration of $\mathrm{CPH}$ at $10 \mathrm{mg} / \mathrm{kg}$ and $20 \mathrm{mg} / \mathrm{kg}$ doses repaired the morphological alterations and supported the rat brain recovery from further injuries. Similarly, rats given CPH 20 $\mathrm{mg} / \mathrm{kg}$ demonstrated significant healing in the affected area of the brain and recovered brain damage compared to rats treated with $\mathrm{CPH} 10 \mathrm{mg} / \mathrm{kg}$ (Fig. 3a).

\section{Reduction of pathological changes in brain sections after chronic administration with chrysophanol}

The brain sections from the vehicle, sham, and CPH $20 \mathrm{mg} / \mathrm{kg}$ perse treatment groups' rats were structurally properly shaped and undamaged, with clearly visible basal ganglia, cortex, and hippocampus tissue. Compared to the vehicle, 
sham, and CPH 20 perse, treated rats, the brain sections of the ICV-PPA treated rats showed cortical and hippocampus atrophy and atrophy in subcortical areas such as the medial thalamus, putamen, caudate nucleus, and internal medullary lamina. Prolonged oral administration of $\mathrm{CPH} 10$ and $20 \mathrm{mg} / \mathrm{kg}$ restored the pathological alterations in rat brain sections (Fig. 3b).

\section{Reduction in demyelination volume after chronic administration with chrysophanol}

The normal, vehicle and $\mathrm{CPH} 20$ perse treated groups had no significant change in the demyelination volume. However, chronic administration of neurotoxin PPA for 11 days significantly enhanced the region of demyelination compared to normal, vehicle, and $\mathrm{CPH} 20$ perse treatment groups. Long-term oral treatment with $\mathrm{CPH}$ at doses of 10 $\mathrm{mg} / \mathrm{kg}$ and $20 \mathrm{mg} / \mathrm{kg}$ significantly reduced demyelination volume compared to PPA-treated autistic-like rats. Consequently, $\mathrm{CPH} 20 \mathrm{mg} / \mathrm{kg}$ showed significant, dose-dependent effect in reducing demyelination volume when compared to $\mathrm{CPH} 10 \mathrm{mg} / \mathrm{kg}$ treated rats [one-way ANOVA: $F(5,25)=0.241, \mathrm{p}<0.001$ ] (Fig. 4).

\subsection{Discussion}

In the current study, a neurotoxin PPA-induced experimental rat model was used to investigate the neurobehavioral and neurochemical alterations in autistic-like rats. Several research studies indicate that ICV-PPA injection plays a major in developing autistic-like behaviour in rats (Rahi et al., 2021; Tiwari et al., 2021; Sharma et al., 2019). PPAexposed rats exhibit behavioural and neuropathological changes similar to those seen in ASD patients, such as hyperactivity, abnormal social interaction, stereotypic and repetitive movements, and are identified as a potential adult ASD model in rodents(Nemechek and Kathryn Moore, 2020; Chow et al., 2012).

Being a weak organic acid, PPA can passively accumulate within CNS cells, leading to a decrease in intracellular pH, with numerous physiological implications (Thomas et al., 2010). PPA has a series of physiological effects that alter brain function, reflecting the enhanced locomotion behaviour observed in PPA-infused rats (Lobzhanidze et al., 2020). It can inhibit Na+/K + ATPase, enhance intracellular calcium release, increase NMDA receptor sensitivity, and elevate nitric oxide, all of which can change neurotransmission in brain areas associated with locomotor behaviour (Meeking et al., 2020; MacFabe et al., 2007). PPA-treated rat brains exhibit microglia and astroglia activation and mitochondrial and fatty acid imbalance, elevated levels of neurotoxic cytokines and oxidative stress markers, and other abnormalities associated with the human ASD findings (MacFabe et al., 2011; Bhandariet al., 2017).

This study induces an experimental model of autism using neurotoxin PPA and investigated that CPH exerts a neuroprotective effect against PPA-mediated behavioural alterations. PPA infusion elicits ASD-like behavioural and neuroinflammatory reactions in rats. It acts as a neurotoxic agent, causing altered behavioural patterns in rats, such as learning and memory impairment, abnormal social interactions, and anxiety-like behaviour (Shultz et al., 2008; Ku et al., 2016; Wu et al., 2017). Furthermore, we evaluated various cellular and molecular markers, apoptotic markers, neurotransmitters, pro-inflammatory cytokines, and oxidative stress parameters levels in rat brain homogenate, blood plasma, and CSF samples. Insights from our behavioural and biochemical observations, long-term oral administration with $\mathrm{CPH}$ at two different doses exhibited a neuroprotective effect against neurobehavioral and neurochemical alterations in the PPA-induced experimental model of autism in rats.

Bodyweight evaluations on different days showed a considerable reduction in body weight after 11 days of ICV-PPA infusion in rats. Prior studies showed that PPA, a short-chain fatty acid, affects weight loss in both animal and 
human individuals due to the altered fatty acid metabolism (Nankova et al., 2014) and excessive gluconeogenesis after entry into the citric acid cycle (Choi et al., 2018). In the current study, this weight loss increased in a dosedependent manner after $\mathrm{CPH}$ administration. We also determined the brain-body weight ratio by dividing the fresh brain weight by the bodyweight at the end of the experimental protocol schedule. The brain-body weight ratio markedly decreased in ICV-PPA-treated autistic rats but increased dose-dependently upon CPH therapy.

The depressive-like behaviour was measured by immobility time during the forced swim test in PPA-induced autistic rats. The present study's findings demonstrated an increase in immobility time following PPA injection, which was attenuated by continuous $\mathrm{CPH}$ administration. The prior research report similarly showed an enhanced depressive effect following PPA treatment (Bhandari et al., 2017).

Previous research indicates that the PI3K/AKT/GSK3/mTOR/BDNF pathway is associated with the development of mood-related illnesses and has also been associated with the adaptive stress response (Lu et al., 2015). Several studies have shown that PI3K/AKT/mTOR has also been implicated in depression and anxiety (Leibrock et al., 2013; Moretti et al., 2014). CPH therapy promotes antidepressant effect by inhibiting the mTOR signalling pathway in a chronic stress model of depression in mice (Zhang et al., 2016). All of these findings supported our study's findings that $\mathrm{CPH}$ reduced depressive symptoms in children with autism.

In addition, the hyperactivity and repetitive behaviours that have been identified as a core symptom of autistic individuals (Kong et al., 2021). PPA and other short-chain fatty acids increase glial and intracellular neuronal acidification and calcium proportions, resulting in huge effects on neurotransmitter release, including serotonin, dopamine, glutamate, and norepinephrine, all of which play a role in the elicitation of locomotor activity (Daghestaniet al., 2017; Thomas et al., 2012).

Furthermore, PPA has been demonstrated to increase glutamatergic transmission, which leads to excitability in brain areas associated with locomotor activity. Our locomotor activity results recorded using actophotometer indicated the increased locomotor activity after ICV-PPA injection, which is similar to the findings of literature studies of Tiwari et al., 2021; Sharma et al., 2019. There was a considerable and dose-dependent improvement in hyperactive and repetitive behaviour after $\mathrm{CPH}$ administration at $10 \mathrm{mg} / \mathrm{kg}$ and $20 \mathrm{mg} / \mathrm{kg}$. The beam crossing task was used to measure the balance and motor coordination by counting the number of slips during movement on a wooden beam. Our findings reveal that PPA autistic rats had an increased number of slips, indicating poor motor coordination, which was decreased in a dose-dependent manner following $\mathrm{CPH}$ treatment. It is commonly known that autistic children have impaired spatial memory, cognitive impairments, and intellectual disabilities (Zhang et al., 2020).

Morris water maze was used to examine long-term memory and spatial learning capabilities. Mepham et al. reported that intracerebroventricular PPA administration showed impaired spatial cognition in adult rats (Mephem et al., 2019). Our analysis revealed that increased ELT and decreased TSTQ resulted in severe memory loss in PPA-treated rats. Furthermore, $\mathrm{CPH}$ treatment reduces the escape latency time (ELT), although increased TSTQ in MWM indicates improved spatial memory.

We also evaluated the effect of $\mathrm{CPH}$ on the PI3K/AKT/mTOR signalling pathway to examine a cellular signalling mechanism. In various studies, PI3K/AKT/mTOR upregulation was associated with the development and progression of neurodegenerative diseases (Bozdagi et al., 2013; Chen et al., 2014). This signalling pathway has recently been implicated in molecular pathways that may contribute to autism (Kwon et al., 2006). In contrast, $\mathrm{PI3K} / \mathrm{AKT} / \mathrm{mTOR}$ signalling pathway inhibition provided a neuroprotective effect used as a diagnostic marker in autistic patients (Yeung et al., 2017). Consequently, we observed increased PI3K/AKT/mTOR levels in PPA-treated 
autistic rats CSF and rat brain homogenate. However, the inhibition of the PI3K/AKT/mTOR pathway by $\mathrm{CPH}$ treatment provides a protective role against autism by reducing cell death, inflammation, oxidative stress, and mitochondrial dysfunction in CSF and rat brain homogenate.

Using advanced techniques, researchers discovered abnormalities in the brain's white matter region associated with the pathology of autism. A prior study found that MBP levels were lower in the brains of autistic patients (GonzalezGronow et al., 2015). The current study observed reduced MBP levels in rat brain homogenate of ICV-PPA rats. Furthermore, $\mathrm{CPH}$ therapy restored MBP levels in brain homogenate in autistic rats.

The neurochemical evaluation in our research provides a strong indication regarding $\mathrm{CPH}$ neuroprotective activity. Neurotransmitters, which play a role in memory, mood, and behavioural regulation, must balance normal functioning and neuronal development. Neurotransmitter dysfunction was discovered to be one of the key causes of the beginning of behavioural characteristics. Neurotransmitter imbalance is one of the significant characteristics of autism (Kuo et al., 2018). In autism, the most studied neurotransmitters include serotonin, dopamine, glutamate, and Ach. Because serotonin is linked to brain development, it is altered in autistic conditions, and its insufficiency contributes to socially impaired, repetitive, and depressed behaviour (Kane et al., 2012; Amodeo et al., 2021).

Additionally, decreased level of dopamine, Ach, and increased glutamate level was also associated with imparting autistic behaviour (Drenthen et al., 2016; Karvat et al., 2014; DiCarlo et al., 2019). Increased glutamate levels activate microglia and promote neuroinflammation, but decreased dopamine and acetylcholine levels affect neuronal excitability, resulted in mood changes (Acharjee et al., 2018). Our analysis revealed that repeated ICV-PPA injection significantly affects the number of neurotransmitters in rat brain homogenates. Dopamine, serotonin, and acetylcholine levels in ICV-PPA-treated rats decreased, but glutamate levels increased considerably, showing neuronal excitotoxicity. $\mathrm{CPH}$ treatment restores the level of neurotransmitters in a dose-dependent manner and ameliorates autistic-like behaviour.

TNF and IL-1 $\beta$ are the key contributors to oxidative damage and neuroinflammation, which are important in neurodegeneration and neurodevelopmental abnormalities (Saghazadeh et al., 2019; Mirza and Sharma, 2019). The clinical study reports on autistic children clearly showed increased inflammatory cytokine levels in CSF, leading to immune response and neuronal damage (Chez et al., 2007). Our study reveals that PPA infusion increased inflammatory cytokines such as TNF and IL-1 $\beta$ in blood plasma and brain homogenate. After treatment with $\mathrm{CPH}$, significantly lowered inflammatory cytokine levels in blood plasma and brain homogenate result in protection against inflammation.

According to previous studies, increased oxidative stress is one of the pathological aspects of autism (Morimoto et al., 2020; Abruzzo et al., 2019; El-Ansary et al., 2012). In order to assess the severity of the condition following ICVPPA injection and the protective effects of $\mathrm{CPH}$ against oxidative stress, we evaluated the levels of oxidative stress markers in brain homogenates of PPA and $\mathrm{CPH}$-treated rats. Our findings clearly show an increase in AchE, LDH, nitrite, and MDA, as well as a decrease in antioxidants, specifically SOD and GSH, in PPA-induced autistic rats. PPAinduced autistic rats treated with $\mathrm{CPH}$ had considerably lower levels of oxidative stress markers, indicating antioxidant capabilities, in a dose-dependent manner.

Excessive cell death hampers brain maturation and is recognized as a potential risk factor in the development of autism (Eftekharian et al., 2019). After PPA exposure, the level of apoptotic markers such as Bax and Caspase 3 increased, whereas the level of anti-apoptotic marker Bcl-2 decreased. Long-term $\mathrm{CPH}$ therapy has been shown to protect cells from cell death by reducing the levels of Bax and Caspase-3 and increasing the levels of Bcl-2.

Page 21/36 
This research looks at the morphological structure of the brain, the whole brain sections, and the demyelination volume. Our previous studies indicate that the hippocampus area was found to be relatively vulnerable to PPA exposure. The histological and morphological finding demonstrates that the brains of PPA-treated rats differ in size and shape (Rahi et al., 2021). Chronic CPH administration improved morphological alterations such as reduced total brain mass, degraded meninges, and constricted prefrontal cortex in ICV-PPA treated autistic rats. Coronal sections of ICV-PPA-treated rats revealed deformed basal ganglia and a defragmented hippocampus area, and degraded white matter.

Moreover, the assessment of demyelination volume in rat brains revealed a substantial decrease in white matter volume following PPA injections (Rahi et al., 2021).Compared to ICV-PPA treated autistic rats, chronic administration with $\mathrm{CPH} 10 \mathrm{mg} / \mathrm{kg}$ and $\mathrm{CPH} 20 \mathrm{mg} / \mathrm{kg}$ recovered the abnormalities in brain sections and enabled the remyelination of degraded areas. It was found that continuous therapy with $\mathrm{CPH}$ reduces the severity of pathological and morphological alterations.

Our research work mainly focuses on the neuroprotective potential of $\mathrm{CPH}$ via downregulating the PI3K/AKT/mTOR signalling pathway and thus mitigating behavioural, neurochemical, morphological, and gross pathological abnormalities in ICV-PPA autistic rats. This study suggests that all of the neurochemical markers investigated could be employed as a useful diagnostic biomarker for the early detection of autism.

However, additional studies for cellular markers, such as Western Blot and immunohistochemistry, are expected to validate these assumptions. Concurrent studies, such as Western Blot and immunohistochemistry, are also necessary to offer molecular evidence for this idea. Despite these limitations, the neuroprotective potential of $\mathrm{CPH}$ in correcting or downregulating the aberrant functioning of $\mathrm{PI} 3 \mathrm{~K} / \mathrm{AKT} / \mathrm{mTOR}$ signalling pathways in the CNS seems promising.

\subsection{Conclusion}

Based on the results, we conclude that PPA injection causes significant alterations, including abnormal neural cell organization, followed by autism-like neurobehaviors and biochemical abnormalities. PPA-treated rats showed aggressive behaviour, and reduced exploratory activity. To date, no pre-clinical studies on the neuroprotective effect of $\mathrm{CPH}$ via downregulation of PI3K/AKT/mTOR signalling in PPA-induced autistic-like rats were reported.

Our findings show that $\mathrm{CPH}$ effectively improves social interaction, learning, and memory deficits in PPA-exposed rats.CPH successfully reduced oxidative stress, neuroinflammation, and neuron death by downregulating the $\mathrm{PI} 3 \mathrm{~K} / \mathrm{AKT} / \mathrm{mTOR}$ signalling pathway in autistic rats. Furthermore, by downregulation of the PI3K/AKT/mTOR pathway in the rat brain, $\mathrm{CPH}$ enhances neuronal proliferation, growth, and differentiation, suppresses cell death and elevates myelin-basic protein levels in PPA-treated autistic-like rats. Furthermore, the rapid recovery of histological and gross morphological abnormalities in the whole brain and brain sections shows $\mathrm{CPH}$ neuroprotective ability against PPA-induced neurological deficits.

Our remarkable findings can be used as diagnostic biomarkers in the early stages of developing a disease-modifying therapeutic compound. However, more genetic research and immuno-histological analysis are required to elucidate the underlying processes regulating such interactions. Indeed, we can consider PI3K/AKT/mTOR as a potential therapeutic target in combination with other standard pharmaceutical treatments.

\section{Abbreviations}


CNS : Central nervous system

mTOR :Mammalian target of rapamycin

PI3K :Phosphoinositide 3-kinase

$\mathrm{CPH}$ : Chrysophanol

AKT : Protein kinase B (PKB)

ASD : Autism spectrum disorder

$A D$ : Alzheimer's disease

ASD : Autism spectrum disorder

BBB : Blood brain barrier

DA : Dopamine

ICV :Intracerebroventicular

PD : Parkinson's disease

PPA : Propionic acid

SOD : Superoxide dismutase

MDA : Malondialdehyde

TNF : Tumor necrosis factor

GSH : Glutathione

LDH : Lactate dehydrogenase

IL-1 $\beta$ : Interleukin-1 $\beta$

HPLC : High performance liquid chromatography

AchE : Acetylcholinesterase

Ach : Acetylcholine

TSTQ : Time spent in target quadrant

ELT : Escape latency time

MWM : Morris water maze

BCT : Beam crossing task

FST : Forced swim test 
MBP : Myelin basic protein

$A D$ : Alzheimer's disease

\section{Declarations}

\section{Acknowledgments}

The authors express their gratitude to Chairman, Mr. Parveen Garg, and Director, Dr. G.D.Gupta, ISF College of Pharmacy, Moga (Punjab), India, for their excellent vision and support.

\section{Data availability statement}

All data generated or analyzed during this study are included in this article. There are no separate or additional files.

\section{Compliance with ethical standards}

\section{Funding}

This work was supported by institutional grants from the Institutional Animal Ethics Committee (IAEC) with registration no. 816/PO/ReBiBt/S/04/CPCSEA as protocol no. IAEC/CPCSEA/Meeting No: 27/2020/Protocol No. 454approved by RAB Committee, ISFCP, Moga, Punjab, India

\section{Disclosure of potential conflicts of interest}

The authors declare that they have no competing interests.

\section{Ethical approval}

All applicable institutional guidelines for the care and use of animals were followed.

\section{Contribution of Authors}

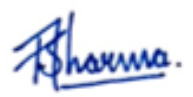

Ms. AartiSharma (First Author)

M. Pharm, Neuropharmacology Division, Department of Pharmacology

ISF College of Pharmacy, Moga, Punjab, India

Contribution: Thesis research work, Performed experimental animal studies 


\section{References}

1. Abd-Elrahman KS, Ferguson SS (2019 Dec) Modulation of mTOR and CREB pathways following mGluR5 blockade contribute to improved Huntington's pathology in zQ 175 mice. Mol Brain 12(1):1-9

2. Abruzzo PM, Matté A, Bolotta A, Federti E, Ghezzo A, Guarnieri T, ... Visconti P (2019) Plasma peroxiredoxin changes and inflammatory cytokines support the involvement of neuro-inflammation and oxidative stress in Autism Spectrum Disorder. Journal of translational medicine 17(1):1-12

3. Acharjee S, Verbeek M, Gomez CD, Bisht K, Lee B, Benoit L, Sharkey KA, Benediktsson A, Tremblay ME, Pittman QJ (Reduced Microglial Activity and Enhanced Glutamate Transmission in the Basolateral Amygdala in Early CNS Autoimmunity. J Neurosci. 2018 Oct 17;38(42):9019-9033. doi: 10.1523/JNEUROSCI.0398-18.2018. Epub 2018) Sep 5. Erratum in: J Neurosci. 2019 May 6;: PMID: 30185466; PMCID: PMC6503215

4. Amodeo DA, Oliver B, Pahua A, Hitchcock K, Bykowski A, Tice D, ... Ryan BC (2021) Serotonin 6 receptor blockade reduces repetitive behavior in the BTBR mouse model of autism spectrum disorder. Pharmacology Biochemistry Behavior 200:173076

5. Bhandari R, Kuhad A (2017 Feb) Resveratrol suppresses neuroinflammation in the experimental paradigm of autism spectrum disorders. Neurochem Int 103:8-23. doi:10.1016/j.neuint.2016.12.012. Epub 2016 Dec 23. PMID: 28025035

6. Bozdagi O, Tavassoli T, Buxbaum JD. Insulin-like growth factor-1 rescues synaptic and motor deficits in a mouse model of autism and developmental delay. Mol Autism. 2013 Apr 27;4(1):9. doi: 10.1186/2040-2392-4-9. PMID: 23621888; PMCID: PMC3649942

7. Brandt C, Hillmann P, Noack A, Römermann K, Öhler LA, Rageot D, Beaufils F, Melone A, Sele AM, Wymann MP, Fabbro D (2018 Sep) The novel, catalytic mTORC1/2 inhibitor PQR620 and the PI3K/mTORC1/2 inhibitor PQR530 effectively cross the blood-brain barrier and increase seizure threshold in a mouse model of chronic epilepsy. Neuropharmacology 15:140:107-120

8. Cassano T, Magini A, Giovagnoli S, Polchi A, Calcagnini S, Pace L, Lavecchia MA, Scuderi C, Bronzuoli MR, Ruggeri L, Gentileschi MP, Romano A, Gaetani S, De Marco F, Emiliani C, Dolcetta D (2019 Jan) Early intrathecal infusion of everolimus restores cognitive function and mood in a murine model of Alzheimer's disease. Exp Neurol 311:88-105 doi: 10.1016/j.expneurol.2018.09.011. Epub 2018 Sep 20. PMID: 30243986

9. Chae U, Min JS, Leem HH, Lee HS, Lee HJ, Lee SR, Lee DS. Chrysophanol Suppressed Glutamate-Induced Hippocampal Neuronal Cell Death via Regulation of Dynamin-Related Protein 1-Dependent Mitochondrial Fission. Pharmacology. 2017;100(3-4):153-160. doi: 10.1159/000477814. Epub 2017 Jun 23. PMID: 28641287

10. Charan J, Kantharia ND (2013 Oct) How to calculate sample size in animal studies? J Pharmacol Pharmacother 4(4):303-306. doi:10.4103/0976-500X.119726. PMID: 24250214; PMCID: PMC3826013

11. Chen J, Alberts I, Li X. Dysregulation of the IGF-I/PI3K/AKT/mTOR signaling pathway in autism spectrum disorders. Int J Dev Neurosci. 2014 Jun;35:35-41. doi: 10.1016/j.ijdevneu.2014.03.006. Epub 2014 Mar 21. PMID: 24662006

12. Chen $Y$, Zheng X, Wang Y, Song J (2019) Effect of PI3K/Akt/mTOR signaling pathway on JNK3 in Parkinsonian rats. Experimental and therapeutic medicine. Mar 1;17(3):1771-5

13. Chez MG, Dowling T, Patel PB, Khanna P, Kominsky M (2007) Elevation of tumor necrosis factor-alpha in cerebrospinal fluid of autistic children. Pediatr Neurol 36(6):361-365 
14. Choi J, Lee S, Won J, Jin Y, Hong Y, Hur TY, ... Hong Y (2018) Pathophysiological and neurobehavioral characteristics of a propionic acid-mediated autism-like rat model. PloS one 13(2):e0192925

15. Chow ML, Pramparo T, Winn ME, Barnes CC, Li HR, Weiss L, Fan JB, Murray S, April C, Belinson H, Fu XD, Wynshaw-Boris A, Schork NJ, Courchesne E (2012) Age-dependent brain gene expression and copy number anomalies in autism suggest distinct pathological processes at young versus mature ages. PLoS Genet 8(3):e1002592. doi:10.1371/journal.pgen.1002592. Epub 2012 Mar 22. PMID: 22457638; PMCID: PMC3310790

16. Chu X, Zhou S, Sun R, Wang L, Xing C, Liang R, Kong Q (2018) Chrysophanol Relieves Cognition Deficits and Neuronal Loss Through Inhibition of Inflammation in Diabetic Mice. Neurochem Res 43(4):972-983. DOI:10.1007/s11064-018-2503-1

17. Colin E, Régulier E, Perrin V, Dürr A, Brice A, Aebischer P, Déglon N, Humbert S, Saudou F (2005 Mar;21(6):147888) Akt is altered in an animal model of Huntington's disease and in patients. Eur $\mathrm{J}$ Neurosci. doi: 10.1111/j.1460-9568.2005.03985.x. PMID: 15845076

18. Daghestani MH, Selim ME, Abd-Elhakim YM, Said EN, El-Hameed NEA, Khalil SR, El-Tawil OS. The role of apitoxin in alleviating propionic acid-induced neurobehavioral impairments in rat pups: The expression pattern of Reelin gene. Biomed Pharmacother. 2017 Sep;93:48-56. doi: 10.1016/j.biopha.2017.06.034. Epub 2017 Jun 14. PMID: 28622594

19. Deng M, Xue Y, Xu L, Wang Q, Wei J, Ke X, Wang J, Chen X (2020 Jan;38(1):47-57) Chrysophanol exhibits inhibitory activities against colorectal cancer by targeting decorin. Cell BiochemFunct. doi: 10.1002/cbf.3445. Epub 2019 Nov 11. PMID: 31710116

20. Deshmukh R*, Sharma V, Mehan S, Sharma N, Bedi KL (2009) Amelioration of intracerebroventricular streptozotocin induced cognitive dysfunction and oxidative stress by vinpocetine -- a PDE1 inhibitor. Eur J Pharmacol. Oct 12;620(1-3):49-56. doi: 10.1016/j.ejphar.2009.08.027. Epub 2009 Aug 21. PMID: 19699735

21. DiCarlo GE, Aguilar JI, Matthies HJ, Harrison FE, Bundschuh KE, West A, ... Galli A (2019) Autism-linked dopamine transporter mutation alters striatal dopamine neurotransmission and dopamine-dependent behaviors. J Clin Investig 129(8):3407-3419

22. Dong HP, Zhou W, Ma XX, He ZZ, Wang ZH. Salvinorin A preserves cerebral pial artery autoregulation after forebrain ischemia via the PI3K/AKT/cGMP pathway. Braz J Med Biol Res. 2018 Mar 15;51(5):e6714. doi: 10.1590/1414-431X20176714. PMID: 29561955; PMCID: PMC5875901

23. Dong $X$, Zhang H (2010) Effects of chrysophanol on learning and memory in AD model mice and mechanism analysis. Chin J Gerontol 30(14):1986-1987

24. Drenthen GS, Barendse EM, Aldenkamp AP, van Veenendaal TM, Puts NA, Edden RA, ... Jansen JF (2016) Altered neurotransmitter metabolism in adolescents with high-functioning autism. Psychiatry Research: Neuroimaging 256:44-49

25. Duggal P, Jadaun KS, Siqqiqui EM, Mehan S. Investigation of Low Dose Cabazitaxel Potential as Microtubule Stabilizer in Experimental Model of Alzheimer's Disease: Restoring Neuronal Cytoskeleton. Curr Alzheimer Res. 2020;17(7):601-615. doi: 10.2174/1567205017666201007120112. PMID: 33030130

26. Eftekharian MM, Komaki A, Oskooie VK, Namvar A, Taheri M, Ghafouri-Fard S. Assessment of Apoptosis Pathway in Peripheral Blood of Autistic Patients. J Mol Neurosci. 2019 Dec;69(4):588-596. doi: 10.1007/s12031-019-01387-9. Epub 2019 Jul 30. PMID: 31363911

27. El-Ansary AK, Ben Bacha A, Kotb M. Etiology of autistic features: the persisting neurotoxic effects of propionic acid. J Neuroinflammation. 2012 Apr 24;9:74. doi: 10.1186/1742-2094-9-74. PMID: 22531301; PMCID:

PMC3425128

Page 26/36 
28. Finegold SM, Downes J, Summanen PH (2012 Apr) Microbiology of regressive autism. Anaerobe 18(2):260262. doi:10.1016/j.anaerobe.2011.12.018. Epub 2011 Dec 22. PMID: 22202440

29. Finegold SM (2011 Aug) Desulfovibrio species are potentially important in regressive autism. Med Hypotheses 77(2):270-274. doi:10.1016/j.mehy.2011.04.032. Epub 2011 May 17. PMID: 21592674

30. Fu K, Chen M, Zheng H, Li C, Yang F, Niu Q (2021) Pelargonidin ameliorates MCAO-induced cerebral ischemia/reperfusion injury in rats by the action on the Nrf2/HO-1 pathway. Translational neuroscience 12(1):020-031

31. Ganesan H, Balasubramanian V, lyer M, Venugopal A, Subramaniam MD, Cho SG, Vellingiri B. mTOR signalling pathway - A root cause for idiopathic autism? BMB Rep. 2019 Jul;52(7):424-433. doi:

10.5483/BMBRep.2019.52.7.137. PMID: 31186084; PMCID: PMC6675248

32. Giacoppo S, Pollastro F, Grassi G, Bramanti P, Mazzon E. Target regulation of PI3K/Akt/mTOR pathway by cannabidiol in treatment of experimental multiple sclerosis. Fitoterapia. 2017 Jan 1;116:77-84

33. González-Fraguela ME, Hung MLD, Vera H, Maragoto C, Noris E, Blanco L, ... Robinson M (2013) Oxidative stress markers in children with autism spectrum disorders. Journal of Advances in Medicine and Medical Research, 307-317

34. Gonzalez-Gronow M, Cuchacovich M, Francos R, Cuchacovich S, Blanco A, Sandoval R, Gomez CF, Valenzuela JA, Ray R, Pizzo SV. Catalytic autoantibodies against myelin basic protein (MBP) isolated from serum of autistic children impair in vitro models of synaptic plasticity in rat hippocampus. J Neuroimmunol. 2015 Oct 15;287:18. doi: 10.1016/j.jneuroim.2015.07.006. Epub 2015 Jul 17. PMID: 26439953

35. Gopi C, Sastry VG, \&Dhanaraju MD (2019) Effect of novel phenothiazine derivatives on brain dopamine in Wistar rats. Beni-Suef University Journal of Basic Applied Sciences 8(1):1-9

36. Guo R, Li G (2018) Tanshinone modulates the expression of Bcl-2 and Bax in cardiomyocytes and has a protective effect in a rat model of myocardial ischemiareperfusion. Hellenic J Cardiol 59(6):323-328

37. Gvozdjáková A, Kucharská J, Ostatníková D, Babinská K, Nakládal D, Crane FL. Ubiquinol improves symptoms in children with autism. Oxid Med Cell Longev. 2014; 2014:798957. doi: 10.1155/2014/798957. Epub 2014 Feb 23. PMID: 24707344; PMCID: PMC3953391

38. Hodges SL, Reynolds CD, Smith GD, Jefferson TS, Nolan SO, Lugo JN. Molecular interplay between hyperactive mammalian target of rapamycin signaling and Alzheimer's disease neuropathology in the NS-Pten knockout mouse model. NeuroReport. 2018 Sep 5;29(13):1109-13

39. Hutsler JJ, Zhang H. Increased dendritic spine densities on cortical projection neurons in autism spectrum disorders. Brain Res. 2010 Jan 14;1309:83-94. doi: 10.1016/j.brainres.2009.09.120. Epub 2009 Nov 6. PMID: 19896929

40. Jafari M, Ghadami E, Dadkhah T, Akhavan-Niaki H (2019 Mar;234(3):2373-2385) PI3k/AKT signaling pathway: Erythropoiesis and beyond. J Cell Physiol. doi: 10.1002/jcp.27262. Epub 2018 Sep 7. PMID: 30192008

41. Jeong HJ, Kim HY, Kim HM (2018 Jan;54:238-244) Molecular mechanisms of anti-inflammatory effect of chrysophanol, an active component of AST2017-01 on atopic dermatitis in vitro models. Int Immunopharmacol. doi: 10.1016/j.intimp.2017.11.019. PMID: 29161660

42. Jiang D, Peng Y (2021 Feb) The protective effect of decoction of Rehmanniae via PI3K/Akt/mTOR pathway in MPP+-induced Parkinson's disease model cells. J Recept Signal Transduct Res 41(1):74-84 doi:

10.1080/10799893.2020.1787445. Epub 2020 Jul 2. PMID: 32611232

43. Jin Y, Wee C-Y, Shi F, Thung K-H, Yap P-T, Shen D, Identification of infants at risk forautism using multi-parameter hierarchical white matter connectomes. Machine learning in medical imaging MLMI (Workshop), author. 9352 
(2015) 170-177. DOI: 10.1007/978-3-319-24888-2_21

44. Kane MJ, Angoa-Peréz M, Briggs DI, Sykes CE, Francescutti DM, Rosenberg DR, Kuhn DM (2012) Mice genetically depleted of brain serotonin display social impairments, communication deficits and repetitive behaviors: possible relevance to autism. PloS one 7(11):e48975

45. Kang DW, Ilhan ZE, Isern NG, Hoyt DW, Howsmon DP, Shaffer M, Lozupone CA, Hahn J, Adams JB, KrajmalnikBrown R. Differences in fecal microbial metabolites and microbiota of children with autism spectrum disorders. Anaerobe. 2018 Feb;49:121-131. doi: 10.1016/j.anaerobe.2017.12.007. Epub 2017 Dec 22. PMID: 29274915

46. Karvat G, Kimchi T (2014) Acetylcholine elevation relieves cognitive rigidity and social deficiency in a mouse model of autism. Neuropsychopharmacology 39(4):831-840

47. Kassai H, Sugaya Y, Noda S, Nakao K, Maeda T, Kano M, Aiba A. Selective activation of mTORC1 signaling recapitulates microcephaly, tuberous sclerosis, and neurodegenerative diseases. Cell Rep. 2014 Jun 12;7(5):1626-1639. doi: 10.1016/j.celrep.2014.04.048. Epub 2014 May 22. PMID: 24857653

48. Kim YC, Guan KL (2015 Jan) mTOR: a pharmacologic target for autophagy regulation. J Clin Invest 125(1):2532. doi:10.1172/JCI73939. Epub 2015 Jan 2. PMID: 25654547; PMCID: PMC4382265

49. Kong Q, Tian P, Zhao J, Zhang H, Wang G, Chen W. The autistic-like behaviors development during weaning and sexual maturation in VPA-induced autistic-like rats is accompanied by gut microbiota dysbiosis. PeerJ. 2021 May 3;9:e11103. doi: 10.7717/peerj.11103. PMID: 33986978; PMCID: PMC8101471

50. Kozler P, Sobek O, Pokorný J (2015) Signs of myelin impairment in cerebrospinal fluid after osmotic opening of the blood-brain barrier in rats. Physiological research, 64, S603

51. Ku KM, Weir RK, Silverman JL, Berman RF, Bauman MD. Behavioral Phenotyping of Juvenile Long-Evans and Sprague-Dawley Rats: Implications for Preclinical Models of Autism Spectrum Disorders. PLoS One. 2016 Jun 28;11(6):e0158150. doi: 10.1371/journal.pone.0158150. PMID: 27351457; PMCID: PMC4924796

52. Kumar M, Dandapat S, Sinha MP, Kumar A, Raipat BS (2017) Different blood collection methods from rats: A review. Balneo Research Journal 8(2):46-50

53. Kuo HY, Liu FC. Molecular Pathology and Pharmacological Treatment of Autism Spectrum Disorder-Like Phenotypes Using Rodent Models. Front Cell Neurosci. 2018 Nov 20;12:422. doi: 10.3389/fncel.2018.00422. PMID: 30524240; PMCID: PMC6262306

54. Kwon CH, Luikart BW, Powell CM, Zhou J, Matheny SA, Zhang W, Li Y, Baker SJ, Parada LF. Pten regulates neuronal arborization and social interaction in mice. Neuron. 2006 May 4;50(3):377 - 88. doi:

10.1016/j.neuron.2006.03.023. PMID: 16675393; PMCID: PMC3902853

55. Lee MS, Cha EY, Sul JY, Song IS, Kim JY (2011 Jun) Chrysophanic acid blocks proliferation of colon cancer cells by inhibiting EGFR/mTOR pathway. Phytother Res 25(6):833-837. doi:10.1002/ptr.3323. Epub 2010 Nov 19. PMID: 21089180

56. Lee JM, Kyeong S, Kim E, Cheon KA (2016) Abnormalities of inter-and intra-hemispheric functional connectivity in autism spectrum disorders: a study using the autism brain imaging data exchange database. Frontiers in neuroscience

57. Leibrock C, Ackermann TF, Hierlmeier M, Lang F, Borgwardt S, Lang UE (2013) Akt2 deficiency is associated with anxiety and depressive behavior in mice. Cell PhysiolBiochem 32(3):766-777. doi:10.1159/000354478. Epub 2013 Sep 13. PMID: 24080829

58. Li G, Lu X, Zhang S, Zhou Q, Zhang L (2015 May) mTOR and Erk1/2 Signaling in the Cerebrospinal FluidContacting Nucleus is Involved in Neuropathic Pain. Neurochem Res 40(5):1053-1062. doi:10.1007/s11064015-1564-7. Epub 2015 Apr 7. PMID: 25846007

Page 28/36 
59. Li N, Lee B, Liu RJ, Banasr M, Dwyer JM, Iwata M, Li XY, Aghajanian G, Duman RS. mTOR-dependent synapse formation underlies the rapid antidepressant effects of NMDA antagonists. Science. 2010 Aug 20;329(5994):959 - 64. doi: 10.1126/science.1190287. PMID: 20724638; PMCID: PMC3116441

60. Li Q, Wu X, Na X, Ge B, Wu Q, Guo X, Ntim M, Zhang Y, Sun Y, Yang J, Xiao Z, Zhao J, Li S (2019) Impaired Cognitive Function and Altered Hippocampal Synaptic Plasticity in Mice Lacking Dermatan Sulfotransferase Chst14/D4st1. Front Mol Neurosci. Feb 11;12:26. doi: 10.3389/fnmol.2019.00026. PMID: 30853887; PMCID: PMC6396735

61. Lian Y, Xia X, Zhao H, Zhu Y (2017) The potential of chrysophanol in protecting against high fat-induced cardiac injury through Nrf2-regulated anti-inflammation, anti-oxidant, and anti-fibrosis in Nrf2 knockout mice. Biomed Pharmacother 93:1175-1189. DOI:10.1016/j.biopha.2017.05.148

62. Lobzhanidze G, Japaridze N, Lordkipanidze T, Rzayev F, MacFabe D, Zhvania M. Behavioural and brain ultrastructural changes following the systemic administration of propionic acid in adolescent male rats. Further development of a rodent model of autism. Int J Dev Neurosci. 2020 Apr;80(2):139-156. doi: 10.1002/jdn.10011. Epub 2020 Feb 25. PMID: 31997401

63. Lu CC, Yang JS, Huang AC, Hsia TC, Chou ST, Kuo CL, Lu HF, Lee TH, Wood WG, Chung JG. Chrysophanol induces necrosis through the production of ROS and alteration of ATP levels in J5 human liver cancer cells. Mol Nutr Food Res. 2010 Jul;54(7):967-76. doi: 10.1002/mnfr.200900265. PMID: 20169580; PMCID: PMC3031088

64. Lu CC, Yang JS, Huang AC, Hsia TC, Chou ST, Kuo CL, Lu HF, Lee TH, Wood WG, Chung JG (2010 Jul) Chrysophanol induces necrosis through the production of ROS and alteration of ATP levels in J5 human liver cancer cells. Molecular nutrition food research 54(7):967-976

65. Lu L, Li K, Mao Y-H, Qu H, Yao B, Zhong W-W, ... Wang Z-Y (2017) Gold-chrysophanol nanoparticles suppress human prostate cancer progression through inactivating AKT expression and inducing apoptosis and ROS generation in vitro and in vivo. Int J Oncol 51(4):1089-1103. DOl:10.3892/ijo.2017.4095

66. Lu Y, Wang C, Xue Z, Li C, Zhang J, Zhao X, ... Zhou W (2015) PI3K/AKT/mTOR Signaling-Mediated Neuropeptide VGF in the Hippocampus of Mice Is Involved in the Rapid Onset Antidepressant-Like Effects of GLYX-13. Int J Neuropsychopharmacol, 18(5). doi:10.1093/ijnp/pyu110

67. MacFabe DF, Cain DP, Rodriguez-Capote K, Franklin AE, Hoffman JE, Boon F, Taylor AR, Kavaliers M, Ossenkopp KP (Neurobiological effects of intraventricular propionic acid in rats: possible role of short chain fatty acids on the pathogenesis and characteristics of autism spectrum disorders. Behav Brain Res. 2007 Jan 10;176(1):149 69. doi: 10.1016/j.bbr.2006.07.025. Epub 2006) Sep 1. PMID: 16950524

68. Maiti P, Manna J, Ilavazhagan G, Rossignol J, Dunbar GL (2015 Dec) Molecular regulation of dendritic spine dynamics and their potential impact on synaptic plasticity and neurological diseases. NeurosciBiobehav Rev 59:208-237 doi: 10.1016/j.neubiorev.2015.09.020. Epub 2015 Nov 10. PMID: 26562682

69. Meeking MM, MacFabe DF, Mepham JR, Foley KA, Tichenoff LJ, Boon FH, Kavaliers M, Ossenkopp KP. Propionic acid induced behavioural effects of relevance to autism spectrum disorder evaluated in the hole board test with rats. Prog Neuropsychopharmacol Biol Psychiatry. 2020 Mar 8;97:109794. doi: 10.1016/j.pnpbp.2019.109794. Epub 2019 Oct 19. PMID: 31639413

70. Mehan S*, Monga V, Rani M, Dudi R, Ghimire K. Neuroprotective effect of solanesol against 3-nitropropionic acidinduced Huntington's disease-like behavioral, biochemical, and cellular alterations: Restoration of coenzymeQ10-mediated mitochondrial dysfunction. Indian J Pharmacol. 2018 Nov-Dec;50(6):309-319. doi: 10.4103/ijp.IJP_11_18. PMID: 30783323; PMCID: PMC6364342 
71. Mehan S*, Rahi S, Tiwari A, Kapoor T, Rajdev K, Sharma R, Khera H, Kosey S, Kukkar U, Dudi R. Adenylate cyclase activator forskolin alleviates intracerebroventricular propionic acid-induced mitochondrial dysfunction of autistic rats. Neural Regen Res. 2020 Jun;15(6):1140-1149. doi: 10.4103/1673-5374.270316. PMID: 31823895; PMCID: PMC7034277

72. Mehan S, Parveen S, Kalra S. Adenyl cyclase activator forskolin protects against Huntington's disease-like neurodegenerative disorders. Neural Regen Res. 2017 Feb;12(2):290-300. doi: 10.4103/1673-5374.200812. PMID: 28400813; PMCID: PMC5361515

73. Mehan S, Verma A, Bedi K, Sehgal V, Meena H, Sharma D (2011) Effect of mitogen activated protein kinase inhibitor in animal model of alzheimer's diseases. International Journal of Pharma Professional's Research, 2(1), 177-188. Retrieved from http://www.ijppronline.in/index.php/IJPPR/article/view/21

74. Mepham JR, Boon FH, Foley KA, Cain DP, MacFabe DF, Ossenkopp KP. Impaired Spatial Cognition in Adult Rats Treated with Multiple Intracerebroventricular (ICV) Infusions of the Enteric Bacterial Metabolite, Propionic Acid, and Return to Baseline After 1 Week of No Treatment: Contribution to a Rodent Model of ASD. Neurotox Res. 2019 May;35(4):823-837. doi: 10.1007/s12640-019-0002-z. Epub 2019 Mar 8. PMID: 30848474

75. Minj E, Upadhayay S, Mehan S. Nrf2/HO-1 Signaling Activator Acetyl-11-keto-beta Boswellic Acid (AKBA)Mediated Neuroprotection in Methyl Mercury-Induced Experimental Model of ALS. Neurochem Res. 2021(a) Jun 1. doi: 10.1007/s11064-021-03366-2. Epub ahead of print. PMID: 34075522

76. Mirza R, Sharma B (2019 Sep) A selective peroxisome proliferator-activated receptor-y agonist benefited propionic acid induced autism-like behavioral phenotypes in rats by attenuation of neuroinflammation and oxidative stress. Chem Biol Interact 25:311:108758. doi:10.1016/j.cbi.2019.108758. Epub 2019 Jul 23. PMID: 31348919

77. Moretti M, Budni J, Freitas AE, Rosa PB, Rodrigues AL (2014 Jan) Antidepressant-like effect of ascorbic acid is associated with the modulation of mammalian target of rapamycin pathway. J Psychiatr Res 48(1):16-24 doi: 10.1016/j.jpsychires.2013.10.014. Epub 2013 Oct 29. PMID: 24209999

78. Morimoto M, Hashimoto T, Tsuda Y, Nakatsu T, Kitaoka T, Kyotani S. Assessment of oxidative stress in autism spectrum disorder using reactive oxygen metabolites and biological antioxidant potential. PLoS One. 2020 May 22;15(5):e0233550. doi: 10.1371/journal.pone.0233550. PMID: 32442231; PMCID: PMC7244111

79. Nankova BB, Agarwal R, MacFabe DF, La Gamma EF. Enteric bacterial metabolites propionic and butyric acid modulate gene expression, including CREB-dependent catecholaminergic neurotransmission, in PC12 cellspossible relevance to autism spectrum disorders. PLoS One. 2014 Aug 29;9(8):e103740. doi: 10.1371/journal.pone.0103740. PMID: 25170769; PMCID: PMC4149359

80. Neis VB, Moretti M, Rosa PB, Dalsenter Y, Werle I, Platt N, Rodrigues ALS (2020) The involvement of $\mathrm{PI3K} / \mathrm{Akt} / \mathrm{mTOR} / \mathrm{GSK} 3 \beta$ signaling pathways in the antidepressant-like effect of AZD6765. Pharmacol Biochem Behav 173020. https://doi.org/10.1016/j.pbb.2020.173020

81. Neumeyer AM, Anixt J, Chan J, Perrin JM, Murray D, Coury DL, Bennett A, Farmer J, Parker RA. Identifying Associations Among Co-Occurring Medical Conditions in Children With Autism Spectrum Disorders. AcadPediatr. 2019 Apr;19(3):300-306. doi: 10.1016/j.acap.2018.06.014. Epub 2018 Jul 24. PMID: 30053632

82. Rahi S, Gupta R, Sharma A, Mehan S. Smo-Shh signaling activator purmorphamine ameliorates neurobehavioral, molecular, and morphological alterations in an intracerebroventricular propionic acid-induced experimental model of autism. Hum Exp Toxicol. 2021 Apr 28:9603271211013456. doi: 10.1177/09603271211013456. Epub ahead of print. PMID: 33906504 
83. Rai SN, Dilnashin H, Birla H, Singh SS, Zahra W, Rathore AS, Singh BK, Singh SP. The Role of PI3K/Akt and ERK in Neurodegenerative Disorders. Neurotox Res. 2019 Apr;35(3):775-795. doi: 10.1007/s12640-019-0003-y. Epub 2019 Feb 1. PMID: 30707354

84. Rajdev K, Siddiqui EM, Jadaun KS, Mehan S. Neuroprotective potential of solanesol in a combined model of intracerebral and intraventricular hemorrhage in rats. IBRO Rep. 2020 Apr 22;8:101-114. doi:

10.1016/j.ibror.2020.03.001. PMID: 32368686; PMCID: PMC7184235

85. Rajni Bala D, Khanna S, Mehan* S, Kalra. Experimental evidence for the potential of lycopene in the management of scopolamine induced amnesia. RSC Advances; 2015 | DOI: 10.1039/c5ra13160j; EID: 2-s2.084940994950

86. Rivière JB, Mirzaa GM, O'Roak BJ, Beddaoui M, Alcantara D, Conway RL, St-Onge J, Schwartzentruber JA, Gripp KW, Nikkel SM, Worthylake T (2012 Aug) De novo germline and postzygotic mutations in AKT3, PIK3R2 and PIK3CA cause a spectrum of related megalencephaly syndromes. Nat Genet 44(8):934-940

87. Rivière JB, Mirzaa GM, O'Roak BJ, Beddaoui M, Alcantara D, Conway RL, St-Onge J, Schwartzentruber JA, Gripp KW, Nikkel SM, Worthylake T (2012 Aug) De novo germline and postzygotic mutations in AKT3, PIK3R2 and PIK3CA cause a spectrum of related megalencephaly syndromes. Nat Genet 44(8):934-940

88. Rokaya MB, Münzbergová Z, Timsina B, Bhattarai KR. Rheum australe D. Don: a review of its botany, ethnobotany, phytochemistry and pharmacology. J Ethnopharmacol. 2012 Jun 14;141(3):761 - 74. doi: 10.1016/j.jep.2012.03.048. Epub 2012 Apr 5. PMID: 22504148

89. Sacai H, Sakoori K, Konno K, Nagahama K, Suzuki H, Watanabe T, Kano M (2020) Autism spectrum disorder-like behavior caused by reduced excitatory synaptic transmission in pyramidal neurons of mouse prefrontal cortex. Nat Commun 11 (1) https://doi.org/10.1038/s41467-020-18861-3

90. Saghazadeh A, Ataeinia B, Keynejad K, Abdolalizadeh A, Hirbod-Mobarakeh A, Rezaei N. A meta-analysis of proinflammatory cytokines in autism spectrum disorders: Effects of age, gender, and latitude. J Psychiatr Res. 2019 Aug;115:90-102. doi: 10.1016/j.jpsychires.2019.05.019. Epub 2019 May 18. PMID: 31125917

91. San Yeung K, Tso WWY, Ip JJK, Mak CCY, Leung GKC, Tsang MHY, ... Chung BHY (2017) Identification of mutations in the PI3K-AKT-mTOR signalling pathway in patients with macrocephaly and developmental delay and/or autism. Molecular autism 8(1):1-11

92. Schipper HM, Chertkow H, Mehindate K, Frankel D, Melmed C, Bergman H (2000) Evaluation of heme oxygenase1 as a systemic biological marker of sporadic AD. Neurology 54(6):1297-1304

93. Shams S, Foley KA, Kavaliers M, MacFabe DF, Ossenkopp KP (2019) Systemic treatment with the enteric bacterial metabolic product propionic acid results in reduction of social behavior in juvenile rats: Contribution to a rodent model of autism spectrum disorder. Dev Psychobiol 61(5):688-699

94. Sharma A, Mehan S (2021 Jul) Targeting PI3K-AKT/mTOR signaling in the prevention of autism. Neurochem Int 147:105067. doi:10.1016/j.neuint.2021.105067. Epub 2021 May 13. PMID: 33992742

95. Sharma R, Rahi S, Mehan S. Neuroprotective potential of solanesol in intracerebroventricular propionic acid induced experimental model of autism: Insights from behavioral and biochemical evidence. Toxicol Rep. 2019 Nov 5;6:1164-1175. doi: 10.1016/j.toxrep.2019.10.019. PMID: 31763180; PMCID: PMC6861559

96. Shultz SR, MacFabe DF, Ossenkopp KP, Scratch S, Whelan J, Taylor R, Cain DP. Intracerebroventricular injection of propionic acid, an enteric bacterial metabolic end-product, impairs social behavior in the rat: implications for an animal model of autism. Neuropharmacology. 2008 May;54(6):901-11. doi:

10.1016/j.neuropharm.2008.01.013. Epub 2008 Feb 13. PMID: 18395759

Page $31 / 36$ 
97. Singh D, Rawat MS, Semalty A, Semalty M (2013) Chrysophanol-phospholipid complex. Journalof thermal analysis and calorimetry. Mar 1;111(3):2069-77

98. Soltani A, Lebrun S, Carpentier G, Zunino G, Chantepie S, Maïza A, Bozzi Y, Desnos C, Darchen F, Stettler O. Increased signaling by the autism-related Engrailed-2 protein enhances dendritic branching and spine density, alters synaptic structural matching, and exaggerates protein synthesis. PLoS One. 2017 Aug 15;12(8):e0181350. doi: 10.1371/journal.pone.0181350. PMID: 28809922; PMCID: PMC5557355

99. Su S, Wu J, Gao Y, Luo Y, Yang D, Wang P (2020) The pharmacological properties of chrysophanol, the recent advances, 125. Biomedicine \& Pharmacotherapy, p 110002

100. Subramanian M, Timmerman CK, Schwartz JL, Pham DL, Meffert MK (2015 Sep) Characterizing autism spectrum disorders by key biochemical pathways. Front Neurosci 24:9:313. doi:10.3389/fnins.2015.00313. PMID: 26483618; PMCID: PMC4586332

101. Sui L, Wang J, Li BM. Role of the phosphoinositide 3-kinase-Akt-mammalian target of the rapamycin signaling pathway in long-term potentiation and trace fear conditioning memory in rat medial prefrontal cortex. Learn Mem. 2008 Oct 2;15(10):762 - 76. doi: 10.1101/Im.1067808. PMID: 18832563

102. Sun $P$, Wei S, Wei $X$, Wang J, Zhang Y, Qiao M, Wu J (2016) Anger Emotional Stress Influences VEGF/VEGFR2 and Its Induced PI3K/AKT/mTOR Signaling Pathway. Neural Plast 2016:4129015. doi:10.1155/2016/4129015. Epub 2016 Feb 14. PMID: 27057362; PMCID: PMC4769761

103. Takei N, Nawa H. mTOR signaling and its roles in normal and abnormal brain development. Front Mol Neurosci. 2014 Apr 23;7:28. doi: 10.3389/fnmol.2014.00028. PMID: 24795562; PMCID: PMC4005960

104. Thomas RH, Foley KA, Mepham JR, Tichenoff LJ, Possmayer F, MacFabe DF (2010 Apr;113(2):515 - 29) Altered brain phospholipid and acylcarnitine profiles in propionic acid infused rodents: further development of a potential model of autism spectrum disorders. J Neurochem. doi: 10.1111/j.1471-4159.2010.06614.x. PMID: 20405543

105. Thomas RH, Meeking MM, Mepham JR, Tichenoff L, Possmayer F, Liu S, MacFabe DF. The enteric bacterial metabolite propionic acid alters brain and plasma phospholipid molecular species: further development of a rodent model of autism spectrum disorders. J Neuroinflammation. 2012 Jul 2;9:153. doi: 10.1186/1742-2094-9153. PMID: 22747852; PMCID: PMC3472254

106. Tiwari A, Khera R, Rahi S, Mehan S, Makeen HA, Khormi YH, Rehman MU, Khan A. Neuroprotective Effect of aMangostin in the Ameliorating Propionic Acid-Induced Experimental Model of Autism in Wistar Rats. Brain Sci. 2021 Feb 25;11(3):288. doi: 10.3390/brainsci11030288. PMID: 33669120; PMCID: PMC7996534

107. Tong X, Zhang J, Shen M, Zhang J (2020 Jan) Silencing of Tenascin-C Inhibited Inflammation and Apoptosis Via PI3K/Akt/NF-KB Signaling Pathway in Subarachnoid Hemorrhage Cell Model. J Stroke Cerebrovasc Dis 29(1):104485. doi:10.1016/j.jstrokecerebrovasdis.2019.104485. Epub 2019 Nov 6. PMID: 31706751

108. Wang JP, Zhang MY (2017) Role for Target of Rapamycin (mTOR) Signal Pathway in Regulating Neuronal Injury after Intracerebral Hemorrhage. Cell PhysiolBiochem 41(1):145-153. doi:10.1159/000455983. Epub 2017 Jan 18. PMID: 28214828

109. Wang Z, Fang J, Xiao J (2019) Correlation of the expression of inflammatory factors with expression of apoptosis-related genes Bax and Bcl-2, in burned rats. Experimental therapeutic medicine 17(3):1790-1796

110. Wu H, Wang X, Gao J, Liang S, Hao Y, Sun C, Xia W, Cao Y, Wu L. Fingolimod (FTY720) attenuates social deficits, learning and memory impairments, neuronal loss and neuroinflammation in the rat model of autism. Life Sci. 2017 Mar 15;173:43-54. doi: 10.1016/j.Ifs.2017.01.012. Epub 2017 Feb 1. PMID: 28161158

Page $32 / 36$ 
111. Xiao Z, Peng J, Yang L, Kong H, Yin F (2015 May) Interleukin-1 $\beta$ plays a role in the pathogenesis of mesial temporal lobe epilepsy through the PI3K/Akt/mTOR signaling pathway in hippocampal neurons. J Neuroimmunol 15:282:110-117

112. Xu Z-X, Kim GH, Tan J-W, Riso AE, Sun Y, Xu EY, Xu B (2020) Elevated protein synthesis in microglia causes autism-like synaptic and behavioral aberrations. Nat Commun 11 (1) https://doi.org/10.1038/s41467-02015530-3

113. Yang G, Wang J, Wan L, Shi XY, Meng Y, Ren WH, Zou LP (2019 Dec) Regulatory role of hippocampal PI3K and mTOR signaling pathway in NMDA-induced infant spasm rats. Neurol Res 41(12):1075-1082 doi: 10.1080/01616412.2019.1672412. Epub 2019 Oct 8. PMID: 31591945

114. Yang W, Liu Y, Xu QQ, Xian YF, Lin ZX. Sulforaphene Ameliorates Neuroinflammation and Hyperphosphorylated Tau Protein via Regulating the PI3K/Akt/GSK-3 $\beta$ Pathway in Experimental Models of Alzheimer's Disease. Oxid Med Cell Longev. 2020 Sep 10;2020:4754195. doi: 10.1155/2020/4754195. PMID: 32963694; PMCID: PMC7502131

115. Yu N, Hu S, Hao Z (2018) Benificial effect of stachydrine on the traumatic brain injury induced neurodegeneration by attenuating the expressions of Akt/mTOR/PI3K and TLR4/NFK-B pathway. Translational neuroscience 9(1):175-182

116. Zhang HB, Tu XK, Chen Q, Shi SS (2019 Dec;28(12):104375) Propofol Reduces Inflammatory Brain Injury after Subarachnoid Hemorrhage: Involvement of PI3K/Akt Pathway. J Stroke Cerebrovasc Dis. doi: 10.1016/j.jstrokecerebrovasdis.2019.104375. Epub 2019 Oct 4. PMID: 31590996

117. Zhang J, Kang H, Wang L, Zhao X (2018) Chrysophanol ameliorates high-fat diet-induced obesity and inflammation in neonatal rats. Die Pharmazie-An International Journal of PharmaceuticalSciences. Apr $2 ; 73(4): 228-33$

118. Zhang J, Yan C, Wang S, Hou Y, Xue G, Zhang L (2014) Chrysophanol attenuates lead exposure-induced injury to hippocampal neurons in neonatal mice. Neural Regen Res. May 1;9(9):924 - 30. doi: 10.4103/16735374.133141. PMID: 25206913; PMCID: PMC4146226

119. Zhang K, Liu J, You X, Kong P, Song Y, Cao L, Yang S, Wang W, Fu Q, Ma Z. P2X7 as a new target for chrysophanol to treat lipopolysaccharide-induced depression in mice. Neurosci Lett. 2016 Feb 2;613:60-5. doi: 10.1016/j.neulet.2015.12.043. Epub 2015 Dec 24. PMID: 26724370

120. Zhang M, Jiao J, Hu X, Yang P, Huang Y, Situ M, Guo K, Cai J, Huang Y. Exploring the spatial working memory and visual perception in children with autism spectrum disorder and general population with high autism-like traits. PLoS One. 2020 Jul 9;15(7):e0235552. doi: 10.1371/journal.pone.0235552. PMID: 32645114; PMCID: PMC7347168

121. Zhang N, Zhang X, Liu X, Wang H, Xue J, Yu J, Kang N, Wang X (2014) Chrysophanol inhibits NALP3 inflammasome activation and ameliorates cerebral ischemia/reperfusion in mice. Mediators Inflamm 2014:370530. doi:10.1155/2014/370530. Epub 2014 Apr 29. PMID: 24876671; PMCID: PMC4020303

122. Zhao Y, Fang Y, Li J, Duan Y, Zhao H, Gao L, Luo Y. Neuroprotective effects of Chrysophanol against inflammation in middle cerebral artery occlusion mice. Neurosci Lett. 2016 Sep 6;630:16-22. doi: 10.1016/j.neulet.2016.07.036. Epub 2016 Jul 20. PMID: 27450437

123. Zhao Y, Fang Y, Zhao H, Li J, Duan Y, Shi W, Huang Y, Gao L, Luo Y. Chrysophanol inhibits endoplasmic reticulum stress in cerebral ischemia and reperfusion mice. Eur J Pharmacol. 2018 Jan 5;818:1-9. doi:

10.1016/j.ejphar.2017.10.016. Epub 2017 Oct 12. PMID: 29031902 
124. Zhao Y, Huang Y, Fang Y, Zhao H, Shi W, Li J, Duan Y, Sun Y, Gao L, Luo Y (2018) Chrysophanol attenuates nitrosative/oxidative stress injury in a mouse model of focal cerebral ischemia/reperfusion. Journal of pharmacological sciences. Sep 1;138(1):16-22

125. Zhao Y, Fang Y, Li J, Duan Y, Zhao H, Gao L, Luo Y (2016) Neuroprotective effects of Chrysophanol against inflammation in middle cerebral artery occlusion mice. Neurosci Lett 630:16-22.

DOI:10.1016/j.neulet.2016.07.036

126. Zheng Z, Zhang L, Zhu T, Huang J, Qu Y, Mu D. Peripheral brain-derived neurotrophic factor in autism spectrum disorder: a systematic review and meta-analysis. Sci Rep. 2016 Aug 10;6:31241. doi: 10.1038/srep31241. PMID: 27506602; PMCID: PMC4979025

\section{Figures}

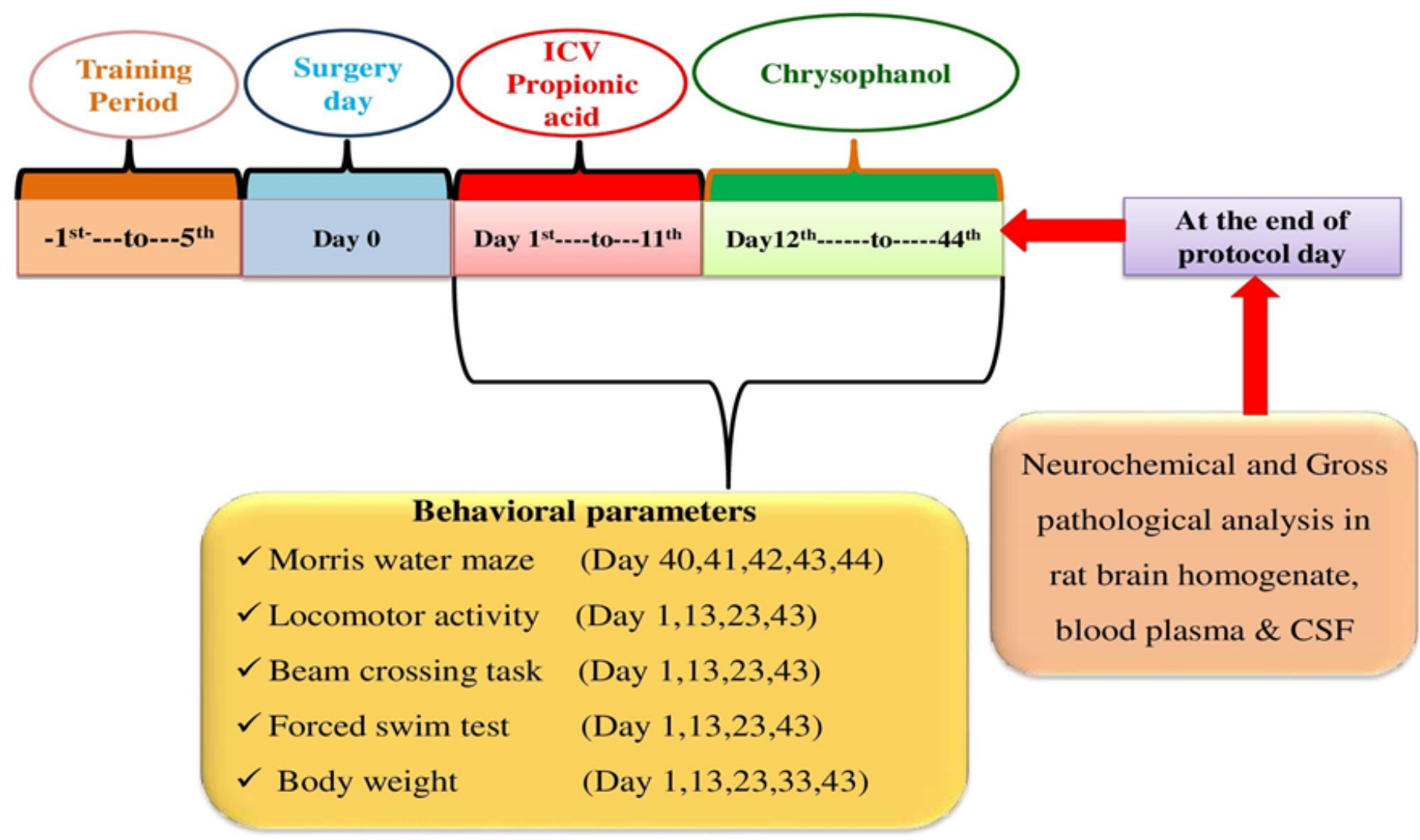

\section{Figure 1}

Experimental protocol schedule (Behavioral and biochemical estimations)
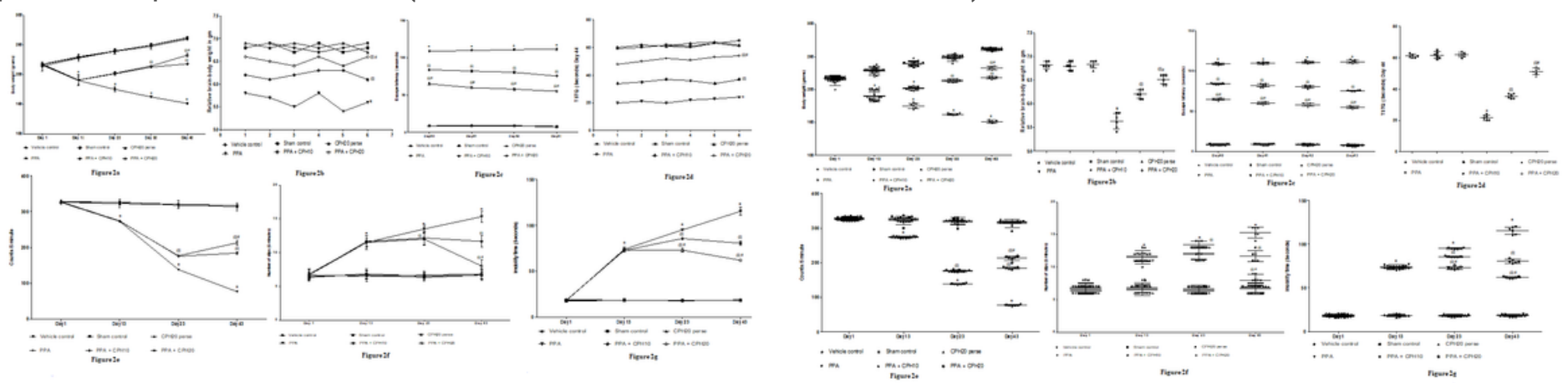


\section{Figure 2}

(a): Effect of chrysophanol on body weight in ICV-PPA induced autism in rats. (Values expressed as mean \pm SD ( $n=6$ rats per group). * $p<0.001 \mathrm{v} / \mathrm{s}$ vehicle control, sham control, and CPH20Perse; @ $p<0.001$ v/s PPA; @\# $p<0.001$ v/s PPA+CPH10 (two-way ANOVA followed by post hoc multiple comparison test Bonferroni) (b): Effect of chrysophanol on relative brain-body weight in propionic acid-induced autism in rats. (Values expressed as mean $\pm S D$ ( $n=6$ rats per group). * $p<0.001 \mathrm{v} / \mathrm{s}$ vehicle control, sham control and CPH20Perse; @ p<0.001 v/s PPA; @\# p<0.001 v/s PPA+CPH10 (one-way ANOVA followed by Tukey's multiple comparison test) (c): Effect of chrysophanol on escape latency time in propionic acid-induced autism in rats. (Values expressed as mean $\pm S D\left(n=6\right.$ rats per group). ${ }^{*} p<0.001 \mathrm{v} / \mathrm{s}$ vehicle control, sham control, and CPH20Perse; @ p<0.001 v/s PPA; @\# p<0.001 v/s PPA+CPH10 (two-way ANOVA followed by post hoc multiple comparison test Bonferroni) (d): Effect of chrysophanol on TSTQ in propionic acid-induced autism in rats. (Values expressed as mean $\pm S D$ ( $n=6$ rats per group). ${ }^{*} p<0.001 \mathrm{v} / \mathrm{s}$ vehicle control, sham control and CPH20Perse; @ p<0.001 v/s PPA; @\# p<0.001 v/s PPA+CPH10 (one-way ANOVA followed by Tukey's multiple comparison test) (e): Effect of chrysophanol on locomotor activity in propionic acid-induced autism in rats. (Values expressed as mean $\pm S D$ ( $n=6$ rats per group). ${ }^{*} p<0.001 \mathrm{v} / \mathrm{s}$ vehicle control, sham control, and CPH20Perse; @ $p<0.001$ v/s PPA; @\# p<0.001 v/s PPA+CPH10 (two-way ANOVA followed by post hoc multiple comparison test Bonferroni) (f): Effect of chrysophanol on neuromuscular coordination in propionic acid-induced autism in rats. (Values expressed as mean $\pm S D$ ( $n=6$ rats per group). ${ }^{*} p<0.001 \mathrm{v} /$ s vehicle control, sham control, and CPH20Perse; @ $p<0.001$ v/s PPA; @\# p<0.001 v/s PPA+CPH10 (two-way ANOVA followed by post hoc multiple comparison test Bonferroni) (g): Effect of chrysophanol on immobility time in propionic acid-induced autism in rats. (Values expressed as mean $\pm S D$ ( $n=6$ rats per group). * $p<0.001 v /$ s vehicle control, sham control, and CPH20Perse; @ $p<0.001$ v/s PPA; @\# $p<0.001 \mathrm{v} / \mathrm{s}$ PPA+CPH10 (two-way ANOVA followed by post hoc multiple comparison test Bonferroni)

\section{Figure 3a}

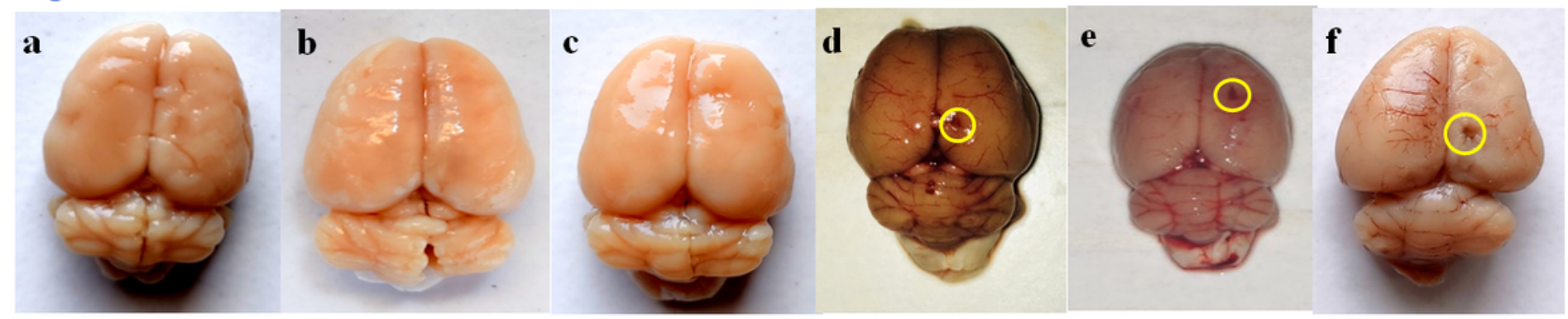

\section{Figure 3b}

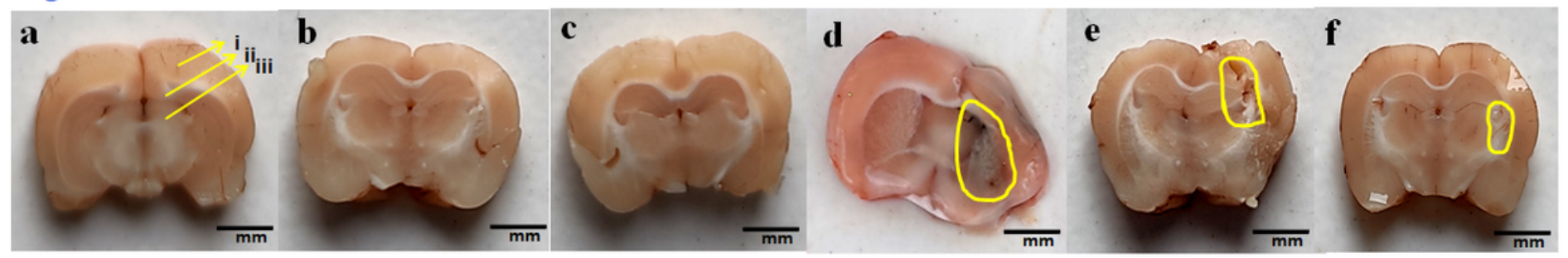

\section{Figure 3}

Effect of chrysophanol in the restoration of gross pathological alterations ofwhole rat brain and brain sections in ICV-PPA induced autism in rats (a) Whole rat brain (a) Vehicle control (b) Sham control (c) CPH20 perse (d) PPA (e) $\mathrm{PPA}+\mathrm{CPH} 10$ (f) PPA + CPH20 (Scale bar = $2 \mathrm{~mm}$ ) Note: Yellow circles are pointing to the site of the brain injury (b) Brain sections (a) Vehicle control (i) Cerebral cortex (ii) Hippocampus (iii) basal Ganglia (b) Sham control (c) $\mathrm{CPH} 20$ perse (d) PPA (e) PPA + CPH10 (f) PPA + CPH20 (Scale bar $=5 \mathrm{~mm}$ ) Note: Yellow circles are pointing to the injured site. 


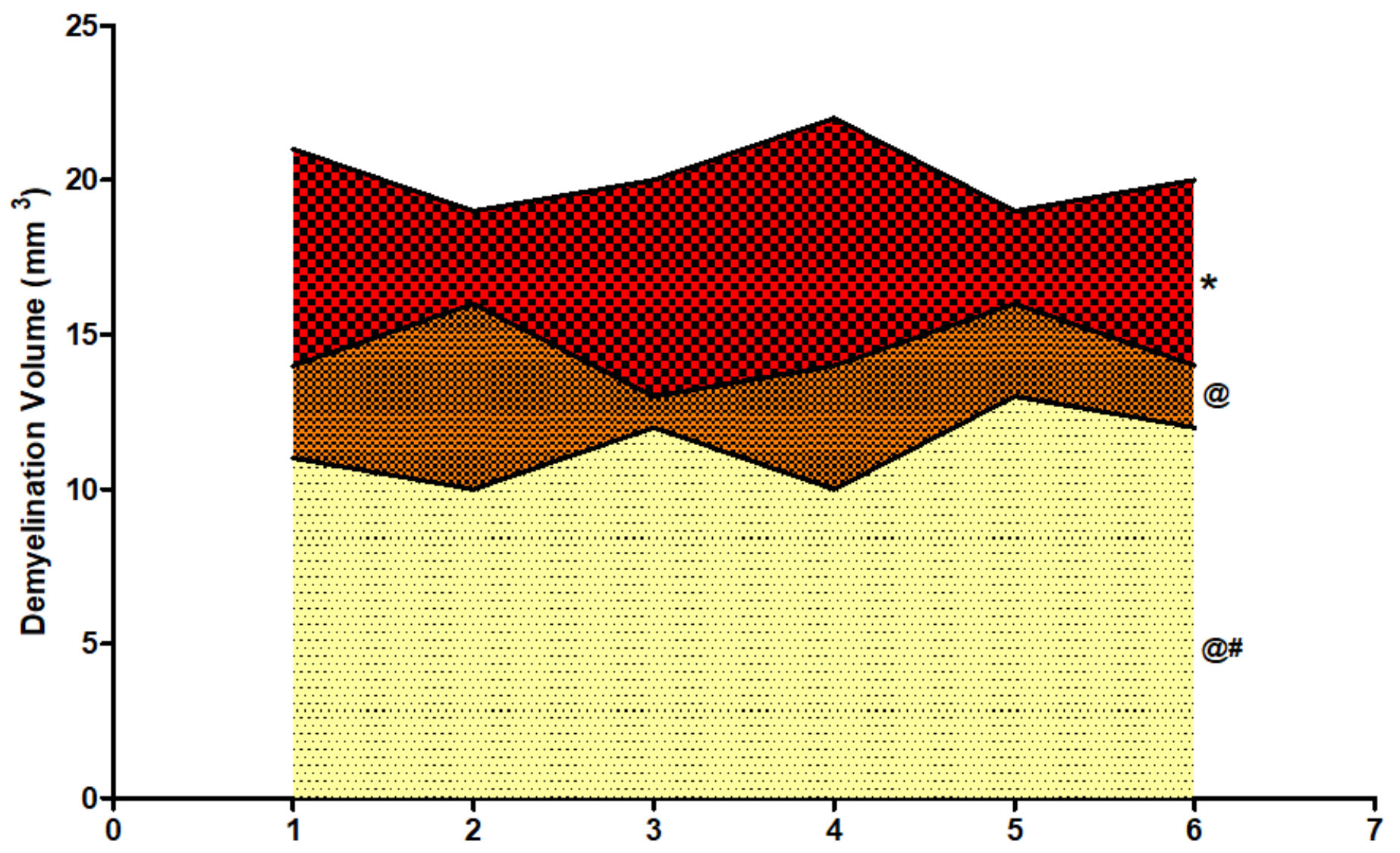

Figure 4

Effect of chrysophanol on demyelination volume in propionic acid-induced autism in rats (Values expressed as mean $\pm S D$ ( $n=6$ rats per group). * $p<0.001 v / s$ vehicle control, sham control and CPH20Perse; @ $p<0.001$ v/s PPA; @\# $\mathrm{p}<0.001 \mathrm{v} / \mathrm{s}$ PPA+CPH10 (one-way ANOVA followed by Tukey's multiple comparison test) 